\title{
Modifications of Plasma Membrane Organization in Cancer Cells for Targeted Therapy
}

\author{
Anna Choromańska ${ }^{1, * \mathbb{D}}$, Agnieszka Chwiłkowska ${ }^{1, *}$, Julita Kulbacka ${ }^{1}$, Dagmara Baczyńska ${ }^{1}$, \\ Nina Rembiałkowska ${ }^{1}{ }^{\mathbb{D}}$, Anna Szewczyk ${ }^{1}$, Olga Michel ${ }^{1}{ }^{\mathbb{D}}$, Agnieszka Gajewska-Naryniecka ${ }^{1}$, \\ Dawid Przystupski ${ }^{2}$ and Jolanta Saczko ${ }^{1}$ (I)
}

1 Department of Molecular and Cellular Biology, Wroclaw Medical University, Borowska 211A, 50-556 Wroclaw, Poland; julita.kulbacka@umed.wroc.pl (J.K.); dagmara.baczynska@umed.wroc.pl (D.B.); nina.rembialkowska@umed.wroc.pl (N.R.); a.szewczyk@umed.wroc.pl (A.S.); michel.olga.maria@gmail.com (O.M.); agnieszka.gajewska-naryniecka@umed.wroc.pl (A.G.-N.); jolanta.saczko@umed.wroc.pl (J.S.)

2 Department of Paediatric Bone Marrow Transplantation, Oncology and Haematology, Wroclaw Medical University, Borowska 213, 50-556 Wroclaw, Poland; dawid.przystupski@student.umed.wroc.pl

* Correspondence: anna.choromanska@umed.wroc.pl (A.C.); agnieszka.chwilkowska@umed.wroc.pl (A.C.)

Citation: Choromańska, A.; Chwiłkowska, A.; Kulbacka, J.; Baczyńska, D.; Rembiałkowska, N.; Szewczyk, A.; Michel, O.;

Gajewska-Naryniecka, A.;

Przystupski, D.; Saczko, J.

Modifications of Plasma Membrane Organization in Cancer Cells for Targeted Therapy. Molecules 2021, 26, 1850. https://doi.org10.3390/ molecules 26071850

Academic Editor: Filippo Minutolo

Received: 23 February 2021

Accepted: 23 March 2021

Published: 25 March 2021

Publisher's Note: MDPI stays neutral with regard to jurisdictional claims in published maps and institutional affiliations.

Copyright: (c) 2021 by the authors. Licensee MDPI, Basel, Switzerland. This article is an open access article distributed under the terms and conditions of the Creative Commons Attribution (CC BY) license (https:/ / creativecommons.org/licenses/by/ $4.0 /)$.

\begin{abstract}
Modifications of the composition or organization of the cancer cell membrane seem to be a promising targeted therapy. This approach can significantly enhance drug uptake or intensify the response of cancer cells to chemotherapeutics. There are several methods enabling lipid bilayer modifications, e.g., pharmacological, physical, and mechanical. It is crucial to keep in mind the significance of drug resistance phenomenon, ion channel and specific receptor impact, and lipid bilayer organization in planning the cell membrane-targeted treatment. In this review, strategies based on cell membrane modulation or reorganization are presented as an alternative tool for future therapeutic protocols.
\end{abstract}

Keywords: plasma membrane; cancer cells; targeted therapy; multidrug resistance; membrane receptors modulation; ion channel modulation; electroporation; sonoporation; microgravity

\section{Introduction}

Currently, researchers focus on the plasma membrane of cancer cells as a promising therapy target [1]. The cell membrane is a natural barrier that determines and regulates the transport of molecules in and out of the cytoplasm. It can be determined by the cell membrane composition, which is dependent on the content of various lipids (e.g., phosphatidylcholine, cholesterol, ceramides) [1-3] and proteins (e.g., channel proteins, receptor proteins, or functional proteins) [4]. Cell membrane organization also plays a role in cell signaling, redox balance, cell death pathways, or metastasis processes $[1,5]$.

Mitigating or softening the lipid bilayer barrier can significantly affect the existing cell functions. However, we should pay attention to the differences in plasma membrane between normal and cancer cells. Basic ones include the shape, i.e., asymmetry, the composition, which is strongly determined by the cholesterol content and defines membrane permeability [3,6]. Rivel et al. showed that the cholesterol molar ratio change from $0 \%$ to $33 \%$ could reduce permeability [6]. It was also shown that the cancer cell membrane varies in the degree of unsaturation compared to normal cells [3]. Certain methods can affect, damage, or modify fluidity and elasticity of the cell membrane, i.e., pharmacological [7], physical (e.g., electroporation [8,9], or sonoporation [10], mechanical (e.g., microcentrifugation or microgravity) [11,12] or genetical [13-15]. The main dilemma is which method based on membrane-lipid therapies would be appropriate for various types of cancers. Each of these methods should be considered individually based on cancer type. This study demonstrates various methods that implicate the plasma membrane modifications, which 
can be a promising target of anticancer therapies. Moreover, this approach may stimulate the development of new therapeutics and treatment protocols in the future.

\section{The Multidrug Resistance Phenomenon and Its Modulators}

\subsection{Types of Cancer Multidrug Resistance and Its Mechanisms}

The multidrug resistance (MDR) phenomenon is one of the main challenges of successful oncological therapy [16]. It is a process in which cancer cells primarily sensitive to a single anticancer compound become resistant to many unrelated drugs that are functionally and/or structurally distinct. Cancer cells become resistant to many chemotherapeutic drugs that have different molecular targets [17]. MDR of cancer cells may result from their primary genetics, which is then called internal MDR. In that variant, cells present primary resistance to chemotherapy before exposure to the cytostatic drugs. The other type is an acquired MDR, which is the more problematic because it leads to ineffective therapies even when the drug concentration is increased to a toxic level [18]. However, not all cancers have the same probability of developing MDR. Its secondary form is prevalent in neoplasms of the kidneys, ovary, bladder, and lymphoblastic leukemia or small cell lung cancer [19]. Primary MDR is characteristic for tumors of the secretory organs such as the liver, colon, or adrenal glands [20]. Multidrug-resistant cells use a variety of defense mechanisms [21]. Most of the tumor MDR strategies involve proteins that have both structural and enzymatic functions. The mechanisms of MDR can be divided into extracellular (external) and cellular (internal). The external ones result from special conditions on the structural level, such as reduced permeability of blood vessels or tissue barriers that prevent drug molecules from penetrating target cells [22]. Heterogeneity is caused by different hydrostatic pressure in distinct parts of the tumor or differences in vascularization. Such heterogeneity may result in the formation of genetically different subpopulations of neoplastic cells, which predispose to significant differences in their response to the chemotherapeutic drug [23]. Internal MDR strategies take advantage of numerous aspects of cell function. In neoplastic diseases, the most common is the transport-dependent MDR, in which the cytostatic do not reach therapeutic concentrations in the cells. This form entails a reduced uptake of drugs from the external environment, resulting from changes in the cytoplasmic membrane structure, hence its permeability to xenobiotics. It also involves the cellular efflux phenomenon based on the active removal of therapeutic molecules from inside the cells via protein-membrane transporters. Difficulties can also occur during the intracellular transport of cytostatic between the nucleus and the cytoplasm. Other internal factors influencing the development of MDR in cancer cells include cell cycle disorders, drug binding in lysosomes or other intracellular organelles [24], drug inactivation by Phase I and Phase II enzymes [17], disruption of the pathways leading to apoptosis. An apoptosis process disturbance occurs via blocking the functionality of proapoptotic proteins and overexpression of proteins operating as programmed death inhibitors. The frequently observed lack of sensitivity to chemo- or radiotherapy is caused by overexpression of antiapoptotic proteins, including Bcl-2 family proteins or apoptosis inhibitors. The cause may also lie in (simultaneous or alternative to overexpression) underexpression of proapoptotic proteins, which also belong to the Bcl-2 family. Bcl-2 family proteins play an essential role in apoptosis regulation. The ratio of pro- and antiapoptotic proteins is the factor deciding about taking or avoiding the programmed cell death pathway. Mutations of the Bcl-2 family (protein p53, genes BAX, and BAK) are often observed in neoplastic cells, which promote the appearance of apoptotic resistance [25]. Another internal factor that can inhibit the action of anticancer drugs is the antioxidant defense system. Most chemotherapeutic agents induce free radical production, and oxidative stress causes damage at the level of proteins, nucleic acids, and cell membranes. Antioxidant mechanisms that protect cells from free radicals also protect cancer cells from free radical damage. These mechanisms are based on the activity of proteins such as superoxide dismutase, catalase, glutathione peroxidase, and cytochromes $[17,26]$. Usually, these enzymes are overexpressed in tumor cells [16]. 


\subsection{Proteins Determining $M D R$}

Most of the known proteins responsible for MDR belong to the ABC family (ATPbinding cassette family). There are 49 identified transporters representing the $\mathrm{ABC}$ family in the human proteome. The most important membrane proteins from that group include P-glycoprotein (P-gp/ABCB1), multidrug resistance-associated protein 1 (MRP1/ABCC1), multidrug resistance-associated protein 2 (MRP2/ ABCC2), breast cancer resistance protein (BCRP/ABCG2) [16]. Their molecules contain two basic structural elements: the membrane-spanning domain (MSD) and located in the cytosol side, the ATP-binding domain, also known as nucleotide-binding folds (NBFs) [27]. The hydrophilic region of NBF is responsible for the binding and hydrolysis of ATP [28]. The energy released in ATP decomposition is used to transport substrates through extracellular and intracellular lipid membranes [29]. Membrane transporters in eukaryotic cells are exporters. They are responsible for removing harmful substances-xenobiotics and natural toxins-from the cytoplasm outside a cell or specific intracellular compartments. ABC transporters enable the functioning of numerous tissue barriers, but their increased expression is responsible for cancer cell resistance [30]. More than $50 \%$ of used anticancer drugs are removed from the cell by the active transport mediated by P-gp transporters. Therefore, there is a tendency to intensify the antitumor activity and decrease the chemotherapeutic systemic toxicity by inhibiting transport mediated by P-gp [31]. P-gp is composed of 1280 amino acids that form two homologous MSD containing six transmembrane domains and two ATP-binding regions, separated by a flexible linker. The secondary structure of the linker region is probably responsible for the coordinated functioning of both P-gp parts. It is responsible for the correct interaction of the two ATP binding domains. The NBFs are located in the cytoplasm and transfer the energy to transport the substrates across the membranes [32].

The xenobiotic removal mechanism by the P-gp has been described in several ways; however, the exact position of the substrate interaction with the protein is not precisely defined [33]. The three main models describing the P-gp mechanism of action are the pore formation model, the flippase model, and the hydrophobic vacuum cleaner model [34]. The last model assumes that P-gp recognizes substrates embedded in the inner layer of the cell membrane and transports them through a protein channel. These substrates are hydrophobic and have a positive charge at physiological $\mathrm{pH}$. However, it was observed that uncharged hydrophilic substrates such as colchicine are also removed from cells by P-gp, suggesting a slightly different mechanism. Rosenberg et al. suggested that P-gp undergoes conformational changes in domains integral with the cell membrane during ATP binding, facilitating translocation of the P-gp substrate [35]. According to the pore formation model, after ATP binding, the transmembrane domains are reorganized along with the entire membrane depth. It creates a central pore through which hydrophobic substrates are removed [36]. Another hypothesis is that P-pg is a flippase that detects the xenobiotic inside the cell membrane and removes it into the extracellular space [31].

\subsection{MDR Modulators}

Based on the knowledge about the P-gp structure and mechanism of action, researchers have been identified substances that modulate the action of P-gp. Due to the action of these substances, the MDR of neoplastic cells can be manipulated to some extent to improve the effectiveness of anticancer therapies. Currently, there are three generations of P-gp inhibitors. First-generation inhibitors, including cyclosporin A, erythromycin, and verapamil [37], originally had a different therapeutic purpose. In their structure, the molecules show a remarkable similarity to the substrates of target transporters [38], and therefore, their competitive activity is inhibited. However, due to its low affinity for MDR proteins, the effectiveness of this generation of chemosensitizers requires their administration in high doses, which leads to severe toxicity [39]. Compounds such as valspodar, dexverapamil or gallopamil, belong to the group of second-generation inhibitors. These modulators have lower toxicity, a better pharmacological profile, but still a low affinity for P-gp [40]. Unfortunately, these substances lack specificity and are competitive 
inhibitors of cytochrome P450 3A4 (CYP3A4). As a result of these reactions, the metabolism of all xenobiotics present in the system is impaired, and the pharmacokinetic profile of the administered cytostatics is disturbed [41]. Failure of therapy with chemosensitizers of the first two groups led to the development of the third generation of MDR modulators. They are characterized by a high affinity for P-gp, which excludes the risk of being associated with other transporters and disrupting their functions. Moreover, when administered in small amounts, they bind to the target protein, forcing a conformational change of the transporter molecule, thus inhibiting its activity and the release of cytostatic molecules outside the tumor cell [42]. This highly promising group of inhibitors includes substances such as tariquidar, biricodar, annamycin, mitotane, and laniquidar [43].

Modulators of other proteins involved in MDR have also been developed. The MRP family proteins are inhibited by MS209 (dofequidar fumarate) [44] and BSO (buthionine sulfoximine), which directly block the formation of glutathione conjugates by GST [42]. In multidrug resistance resulting from cellular crypts and LRP, the pyridine derivative (PAK-104P) is used as a modulator [42]. BCRP inhibition enables elacridar, tariquidar, biricodar, which are P-gp inhibitors [45], as well as fumitremorgin C (FTC) and dietary herbal components [46]. Plant-derived substances can influence the modulation of P-gp activity and expression. Notably, some of them, by inhibiting P-gp, sensitize cancer cells to conventional chemotherapy without undesirable toxic effects. They also do not show their pharmacological activity [47].

It has been noticed that inhibition some signal pathways, for example PI3K/AKT pathway, can ability to reverse cancer MDR. Zhang et al. have been reported that, through the specific inhibition of PI3K $110 \alpha$ and $110 \beta$ subunits by BAY-1082439, which is a highly selective PI3K inhibitor and via Crispr/Cas9 gene knockout method, P-gp/ABCB1 and $\mathrm{BCRP} / \mathrm{ABCG} 2$ were downregulated and the drug sensitivity was reestablished in human epidermoid carcinoma and non-small cell lung cancer (NSCLC) MDR cells. [48].

Another method of abolishing MDR related to membrane transport activity is the use of antibodies against this transporter [37] and small-molecule kinase inhibitors-sunitinib or apatinib. They can inhibit the transport proteins of the ABC family by blocking their active sites responsible for ATP hydrolysis and providing the energy necessary for the ejection of substrate molecules from the cell [41].

\section{Modulators of Natural Origin}

A large proportion of the flavonoids are specific inhibitors of the P-gp transporter [31,49]. Several mechanisms can modulate P-gp. The substrate-binding site may be blocked [34], the ATP binding sites may be affected [50], the ATP hydrolysis reaction may be disrupted [51], the lipid integrity of the cell membrane may be altered [52], and the level of P-gp expression can be reduced [48,53] (Figure 1).

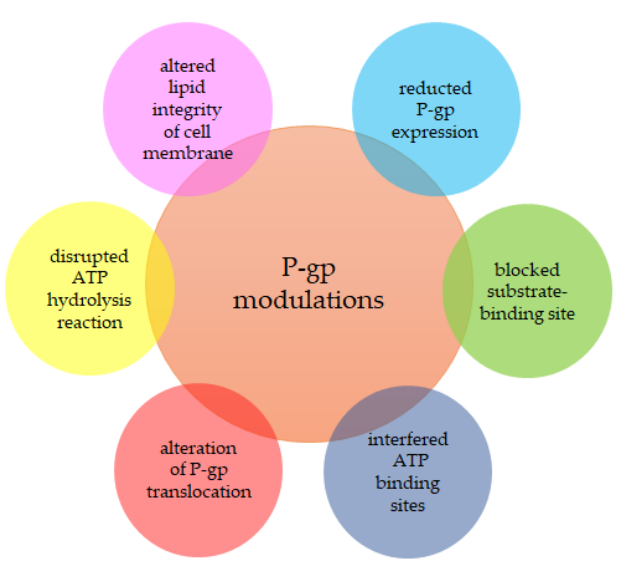

Figure 1. Mechanisms of P-gp modulations [31,34,48-53]. 
Compounds that inhibit ATP hydrolysis are potentially better inhibitors of P-gp because they are unlikely to be P-gp substrates. As a result, such substances can be applied at a low dose. So far, no modulator has been found that can interact with the ATP binding site to disrupt the P-gp ATPase catalytic cycle. Substances with such a mechanism of action are sought. They would provide better inhibitors with high specific activity. The modulation mechanism induced by plant modulators is largely undefined [31]. It was shown that some flavonoids could change the order of lipid packing in the membrane and thus change the fluidity or permeability of the membrane [54]. The influence of flavonoids on drug accumulation may result from their non-specific interaction with the cell membrane, which results in the increased passive permeability of the membranes [55]. Another possibility may be a flavonoid-induced decrease in P-gp expression in P-gp overexpressing cells. One of the potential mechanisms responsible for modulating the action of P-gp by flavonoids may also be the inhibition of P-gp ATPase through the direct interaction of the flavonoid with the ATP binding site [56]. It has been shown that flavonoids, including genistein, catechin gallate, epigallocatechin gallate, epicatechin gallate, and silymarin, can directly bind to the P-gp substrate via the substrate's P-gp binding site [57]. Besides, it was found that some flavonoids directly interact with the ATP-binding domain of P-gp [58]. However, different flavonoids may interact differently with P-gp since opposite effects on P-gp ATPase activity were observed for various flavonoids [59]. The structural activity of the flavonoids has a significant influence on the activity of the P-gp interaction. The presence of the 5-hydroxyl group, the 3-hydroxyl group, and the double bond causes a strong interaction of the flavonoid with the ATP-binding domain in P-gp [59]. Various results were reported regarding the P-gp modulating activity of some flavonoids. Yeh et al. demonstrated that kaempferol and quercetin stimulate doxorubicin efflux mediated by P-gp [60,61], while Scambia et al. reported that quercetin inhibits doxorubicin efflux from tumor cells [62]. Shapiro and Ling showed that quercetin inhibited P-gp-mediated transport of the fluorescent probe, at least in part by inhibiting P-gp ATPase activity [63]. The efficacy of chronic oral chemotherapy is highly dependent on the P-gp transporters present in the intestinal endothelium. Flavonoids can be nontoxic P-gp inhibitors, significantly improving the bioavailability of chemotherapeutic agents. Choi et al. conducted numerous studies based on the inhibition of P-gp with flavonoids. In vivo studies showed that orally administered paclitaxel and flavone (naringin) significantly increased paclitaxel bioavailability compared to samples where paclitaxel was used alone [64]. First-generation P-gp modulators have undesirable side effects, which explains the interest in flavonoids as nontoxic P-gp inhibitors. The importance of flavonoid-transporter interactions in the pharmacokinetic mechanisms is yet to be well demonstrated. Therefore, further detailed studies are needed to assess the in vivo impact of flavonoids on the bioavailability of drugs and identify and predict potential interactions with drugs [31].

In the past decade, knowledge of weak points of MDR mechanisms enabled scientists to develop new strategies against MDR cancer cells. In addition to the above-mentioned MDR modulators, a lot of novel potential anticancer agents have been designed to overcome these mechanisms $[65,66]$.

\section{MicroRNAs as Regulators of MDR Gene Expression}

As was described earlier, one of the major problems of clinical treatment in anticancer therapy is multidrug resistance (MDR). The MDR mechanism includes active drug efflux transport of $\mathrm{ABC}$ superfamily of proteins, which destroys chemotherapeutic effectiveness and undoes/defeats anticancer therapy. The goal of researchers is to find a way to outsmart these mechanisms. Next to the strategies to overcome MDR in cancer cells described above, others that involve the use of microRNAs (miRs or miRNAs) are being developed.

The so-called miRs represent a class of single-stranded non-coding RNAs with a length of approximately 20 to 25 nucleotides [67]. They have significant roles in the post-transcriptional control of gene expression. They act through RNA interference by forming imperfect hybrids with target mRNAs leading to mRNA degradation or translation 
inhibition [67] by binding to the target mRNA $3^{\prime}-\mathrm{UTR}, 5^{\prime} \mathrm{UTR}$, or the coding region $[68,69]$. In rare circumstances, dependent on cell cycle and co-factors, miRs can also function as positive regulators of gene expression by binding to protein-coding exons or the $5^{\prime} \mathrm{UTR}$ region. It was suggested that miRs might also bind to the promoter region of genes [70-73].

Significant alterations of miR expression profiles were observed between cancerous cells and normal tissues from the same organ or in drug-resistant cancer cells compared to parental drug-sensitive cancer cells. This finding gives rise to the search for miRs that could regulate MDR.

P-gp is the best-characterized efflux pump mediating MDR. Its regulation appears to be a complex and highly controlled process that can be predominantly regulated at the transcriptional and post-transcriptional levels. The miRs reported as MDR-1/P-gp regulators and reviewed in [74] miRs described as direct regulators of P-gp cause an inverse correlation between the expression of miRs and P-gp mRNA levels. The decrease in MDR-1 expression and consequently an increase in cellular sensitivity to doxorubicin was observed after the increase of the cellular levels of miR-451 in a doxorubicin-resistant breast cancer cell line (MCF-7/DOX) [75], miR-331-5p in resistant K562/DOX leukemia cells [76], and miR-27a in a chronic myeloid leukemia cell line (K562) [76]. This group of direct regulators also includes miR-298, which was significantly downregulated in the doxorubicin-resistant MDA-MB-231 cells compared to the doxorubicin-sensitive MDA-MB-231 cells [77]. It was reported that miR-298 downregulation caused an increase of P-gp expression and induced resistance to doxorubicin in breast cancer cells (MDA-MB-231) [77]. Direct regulation of MDR-1 was also described for miR-145. The downregulation of miR-145 in Caco-2 cells increased P-gp expression but not MDR1 mRNA level [78]. Feng et al. showed that miR$331-5 p$ and miR-27a are inversely correlated with the expression of a drug-resistant factor, $\mathrm{P}$-glycoprotein (P-gp), in leukemia cell lines with gradually increasing resistance [76].

Moreover, miRs can also act at the post-transcriptional level as indirect regulators by targeting other mRNAs that code for intermediate proteins or transcription factors engaged in MDR-1 gene activation and affecting other factors, which modulate P-gp expression. As mentioned above, direct regulator miR-27a can also indirectly modulate MDR1 mRNA and P-glycoprotein expression by targeting homeodomain-interacting protein kinase-2 in human ovarian cancer cells [79]. It was shown that miR-508-5p could associate with the $3^{\prime}$ UTR regions of both $\mathrm{ABCB} 1$ and zinc ribbon domain-containing 1 (ZNRD1) and suppress their expression at mRNA and protein level [80]. As a result of overexpression of miR-508$5 p$ in human gastric cancer cell line SGC7901, the resistance to multiple chemotherapeutics in vitro and tumor sensitivity to chemotherapy in vivo were reversed [80]. By increasing the level of miR-21 via the presence of hyaluronan, a decrease in the levels of the tumor suppressor protein programmed cell death 4 (PDCD4) was observed in a doxorubicinresistant breast tumor cell line MCF-7. Using an anti-miR-21 inhibitor to silence miR-21 expression enhances the PDCD4 expression [81].

The indirect upregulating impact of the miR on P-gp expression via repressive transcription factors, such as BMI1 polycomb ring finger oncogene (BMI-1), cyclooxygenase 2 9COX20, homeodomain-interacting protein kinase 2 (HIPK2), macrophage migration inhibitory factor (MIF), Y-box binding protein 1 (YB1), zinc finger E-box-binding homeobox 1 (ZEB1), was reviewed in [82]. The increase in the cellular level of some miR was shown to increase the sensitivity of resistant cells to cisplatin, epirubicin, paclitaxel, doxorubicin, vincristine, and fluorouracil [73]. In addition to post-transcriptional regulation, the involvement of miR-27a acting at the transcriptional level was reported. The downregulation of miR-27a could reverse drug resistance and decrease the expression of P-gp in ECA-109 squamous cell carcinoma of the esophagus [73] and MKN45 gastric cancer cells [83]. Zhao et al. [71] postulated that the upregulation of miR-138 could downregulate P-glycoprotein expression and the transcription of the MDR-1 gene. Additionally, overexpression of miR-138 promotes adriamycin-induced apoptosis in leukemia cells [83].

Other recent works also demonstrated that some miRNAs might regulate the expression of the next ABC through their actions on $A B C 3^{\prime} U T R$ or miR-210-3p negatively 
regulated $\mathrm{ABCC} 1$ and improved drug-sensitivity of renal cell carcinoma Caki-2/VBL and Caki-2/DOX [84]. Overexpression of miR-328 in MCF-7/MX100 breast cancer cells decreased the level of ABCG2 mRNA and protein and, more importantly, increased sensitivity to mitoxantrone [85]. The researchers cannot exclude the possibility that miR-328 also targets the transcriptional factors of ABCG2, leading to indirect transcriptional regulation of ABCG2 [85].

It was shown that an increased miR-200c level might cause an indirect transcriptional regulation of ABCG2 by targeting transcription factors such as BMI- 1 in melanoma cells [86] and ZEB1 in human breast cancer cells [87].

A search for potential regulatory miRs may occur with the participation of bioinformatics tools. Medarova et al. [88] chose unexplored miRs with high nucleotide sequence correspondence to two representative MDR proteins, MGMT and ABCB1. They demonstrated that therapeutic miRs could be identified based on the nucleotide sequence matching miRs to targeted mRNA.

A diversity of miR expression profiles and the observed significant influence of miR level changes on MDR gene expression modifications indicate that miRs could be ideal biomarkers of diseases and candidates in drug therapy management.

\section{Anticancer Therapies Targeting Ion Channels}

As part of cell membranes, ion channels (IC) play an important role in ion homeostasis, cellular osmolarity, and signaling regulation, contributing to the cell cycle, proliferation, migration, adhesion metabolism, and apoptosis. The extra- and intracellular environment changes during neoplastic transformation induce remodeling of the cell membrane and modifications in ion channel expression and activity. The aberrant expression of a wide range of ion channels was detected in many types of cancers as reviewed elsewhere [89,90]. Inversely, altered expression and activity IC can lead to tumorigenicity and the formation of metastatic potential. These findings stimulate research into the practical implementation of ion channels as targets in cancer diagnostics and therapy. This chapter focuses on the main anticancer strategies based on IC and discusses examples of their application. As a complementary review of ion channel inhibitors, we refer to [91].

The regulation of IC is a key element in the treatment of many cardiovascular and neurological diseases. Natural and synthetic inhibitors of ion channel activity used in such therapies are potential anticancer drugs. Imipramine, used as an antidepressant drug, inhibits potassium voltage-gated channel $\mathrm{KCNH} 1$. Interestingly, $\mathrm{KCNH} 1$ is reported to be upregulated in many cancers, including breast, lung, prostate, and colon; thus, its use is postulated as an early tumor marker and prognostic marker as well [92]. It has recently been demonstrated that imipramine can be successfully adapted to suppress DU145 prostate cancer cells [93]. However, this tricyclic antidepressant also interacts with other ion channels on neuronal and cardiac cells, which may lead to different cardiovascular side effects; thus, its clinical application may be limited [94,95]. On the other hand, imipramine blue, its analog, inhibits progression and metastasis of breast cancer cells, although the compound's low toxicity was proven only in the animal model [96]. Another member of the potassium voltage-gated channel is $\mathrm{KCNH} 2$ which is inhibited by fluoxetine (Prozac), a popular serotonin reuptake inhibitor and a neurological disorder drug. Interestingly, fluoxetine also enters mitochondria, where it inhibits ATP production. Consequently, $\mathrm{Ca}^{2+}$ leakage from the endoplasmic reticulum is accompanied by ORAI-1- mediated extracellular $\mathrm{Ca}^{2+}$ entry, leading to an increase of ion concentration in the cytoplasm and mitochondria [97]. The anticancer properties of fluoxetine were confirmed in many cancer models, both in vitro and in vivo $[98,99]$. However, some recent studies support its pro-survival potential as well $[100,101]$. An example of antiarrhythmic agents that can be potentially used in anticancer therapy is verapamil. It acts mainly as an inhibitor of L-type calcium channels, although it was reported to block KCNH2 [102,103]. Antiproliferative verapamil activity was shown in many neoplasms, among others in melanoma and breast cancer $[104,105]$. Moreover, verapamil enhances paclitaxel's effectiveness in chemoresistant cancer cells via 
ABCB1 (MDR1) modulation [106]. Similarly, many other antagonists of IC are used in combination with well-known anticancer drugs with satisfactory results. Mibefradil, an antihypertensive drug, blocks T-type calcium channels and KCNH1, giving promising results together with temozolomide in high-grade glioblastoma therapy. It is noteworthy that despite profitable inhibition of $\mathrm{Ca}^{2+}$ influx into tumor cells by mibefradil, it should be used with the utmost care due to the risk of cross-reactions with other drugs [107].

Many natural compounds can regulate the activity and expression of ion channels. Calcitriol is an endogenously synthesized compound, which modulates intracellular signaling pathways through the vitamin D receptor (VDR). Among others, the KCNH1 expression is decreased in calcitriol- treated cancer cells. Interestingly, therapy combined with astemizole enhances calcitriol bioavailability and reduces its dose, leading to growth inhibition of breast cancer cells in vitro and in vivo [108,109]. Moreover, concomitant administration of calcitriol with other natural compound resveratrol or curcumin results in reduced tumor volume of triple-negative breast cancer cells [110]. Furthermore, resveratrol can induce the expression of ATPase sarcoplasmic/endoplasmic reticulum $\mathrm{Ca}^{2+}$ transporting 3 (ATP2A3, SERCA3) in breast cancer cells. As a consequence, the concentration of cytoplasmic calcium ions changes, which stimulates death. It has been recently shown that resveratrol induces SERCA3 through epigenetic modification of the ATP2A3 gene [111,112]. In contrast, curcumin and its derivative RL71 (3,5-bis(3,4,5-trimethoxybenzylidene)- 1-methylpiperidin4-one) directly inhibit ATP2A2 (SERCA2) and activate ER-stress associated apoptosis [113].

It was demonstrated that some natural animal toxins interact directly with voltagedependent potassium, chloride, and calcium channels. Chlorotoxin (CTX) is a neurotoxic peptide originally found in the venom of an Israeli scorpion, which inhibits chloride channels. Some evidence indicates that the main target of CTX is metalloproteinase 2 (MMP-2), which can form a complex with chloride voltage-gated channel 3 (CLCN3). The endocytosis of the complexes induced via binding of CTX contributes to chloride ion efflux in cells $[114,115]$. Synthetic chlorotoxin derivatives were used successfully in both preclinical and clinical trials of glioma therapies [116-118]. Potassium transporters play a crucial role in cell membrane potential. Concomitantly, the deregulation of the $\mathrm{K}^{+}$channel expression is predominantly observed in many tumors [119]. Iberiotoxin (IBTX) and charybdotoxin (CTX) are other scorpion venom peptides, selective modulating a voltagedependent large-conductance $\mathrm{Ca}^{2+}$ activated $\mathrm{K}^{+}$channel (KCNMA1). Human metastatic breast cancer cells with overexpression of KCNMA1 have diminished the migratory and invasive properties after treatment with IBTX. Similar effects were observed in cells with direct silencing of KCNMA1 expression through RNAi [120]. Furthermore, IBTX turned out to be an effective inhibitor of prostate cell proliferation, while CTX decreased the migration potential of melanoma cells [121,122]. Potassium small conductance calciumactivated channels are inhibited by other scorpion toxins of the $\alpha \mathrm{KT}$ x 5 family (e.g., apamin, scyllatoxin, PO5), which differ in the channel member selectivity. Among them, tamapin exhibits the highest selectivity for the KCNN2 channel and induces the death of Jurkat T cells and MDA-MB-2 breast cancer cells [123,124]. Recently, the mutant E25K/K27E of tamapin has been shown to be an effective blocker of KCNN3, leading to inhibition of MDAMB-435s cell migration. These results indicate that directed-mutagenesis of known, natural ion channel inhibitors can be used in drug design for selective anticancer therapies [125].

Hypothetically, good selectivity of IC inactivation and anticancer treatment should lead to immunotherapies based on monoclonal and polyclonal antibodies. However, this strategy is mainly applied for sensitive and selective cancer cell detection, although some use whole antibodies or their fragments directly in cancer therapies has been presented [126]. The application of polyclonal antibodies, targeting 17-amino acid fragments of non-functional ATP-gated receptor $\mathrm{P}_{2} \mathrm{X}_{7}$, confirmed its therapeutic potential in Phase I of the clinical trial concerning basal cell carcinoma [127]. P2 $X_{7}$ is a membrane receptor working as a non-selective cation channel in response to rapid exposure of ATP. However, prolonged ATP stimulation causes uncontrolled pore opening and allows the transport of larger molecules that regulate the survival/death balance in the cells. Simultaneously, high 
ATP concentration provides the dominant expression of the non-pore functional form of $\mathrm{P} \mathrm{X}_{7}\left(\mathrm{nfP} 2 \mathrm{X}_{7}\right)$, essential for cancer cell survival, which indicates that $\mathrm{nfP}^{2} \mathrm{X}_{7}$ can be a selective and attractive target for cancer therapies. [128]. Despite the remarkable development of many anticancer therapies based on the chimeric antigen receptor T-cells, there are no studies on targeting ion channels by this method to our knowledge.

Alternative methods directed at regulating ion channel expression in cancer cells could include gene therapies based on RNAi or CRISPR/Cas9. This strategy allows for satisfactory results with no effects on other ion channels compared to most chemical blockers. Transient receptor potential melastatin 2 (TRPM2) belongs to non-selective cation channels. Its role in regulating cancer growth and metastasis was confirmed by many studies $[129,130]$. On the other hand, selective downregulation of TRPM2 via shRNA results in the proliferation decrease and apoptosis promotion in gastric and lung cancer cells. Notably, TRPM2 silencing also enhances the effectiveness of chemotherapy with paclitaxel and doxorubicin [131,132]. Similarly, the use of selective shRNA and siRNA targeting KCNH1 and ORAI1 leads to an increase in cancer cell sensitivity to chemotherapeutic drugs $[133,134]$. Furthermore, possible microRNA- and CRISP/Cas9-mediated IC expression was also found $[135,136]$. However, these strategies are usually limited to cellular models, probably due to ethical and legal restrictions.

Electromagnetic field or photothermal therapy stimulates cellular internal and external membranes, leading to their remodeling. One of the consequences of using such methods is the regulation of multiple ion channels simultaneously, which leads to altered ion fluxes. Despite poor selectivity, both electromagnetic field pulses and photodynamic reactions are shown to be efficient in many anticancer therapies [137-139]. On the other hand, the exact mechanism of these stimuli is still poorly understood and difficult for prediction due to the multifactorial nature of induced processes [140].

\section{Plasma Membrane Receptors and Modulations}

\subsection{The Mechanism of Signal Transduction from The External Environment to The Cell by} Integral Membrane Receptor

Normal and pathological eukaryotic cells are surrounded by a cell membrane that protects them against damaging factors and allows them to contact the external environment [141]. Eukaryotic cells have the capacity to receive, select, analyze and respond to signals received from the environment and other cells of a multicellular organism. Therefore, intercellular signaling is a necessary process for the functional integration of multicellular organisms. Many aspects of cell function, such as metabolic regulation, survival, proliferation, differentiation, and death, are dependent on appropriately effective systems involved in cell signaling. Chemical compounds, called ligands, transmit information and play a significant role in balancing and synchronizing life processes throughout the cells and the body [141]. Communication between single cells in a multicellular organism acts by synthesizing ligands, either released or presented on their surface, that interact with receptors, either inside the target cell or on its surface. Ligands are released in small, usually volatile or soluble molecules, including proteins, peptides, fatty acids, steroids, gases, and other low-molecular-weight compounds [141].

The membrane receptors associated with signaling are integral membrane proteins. Their structure includes extracellular (acceptor), transmembrane, and intracellular (effector) parts. The acceptor domain binds ligand specifically and reversibly. The transmembrane part anchors the receptor in the cell membrane. The effector domain can generate and amplify the signal inside the cell (Figure 2). 


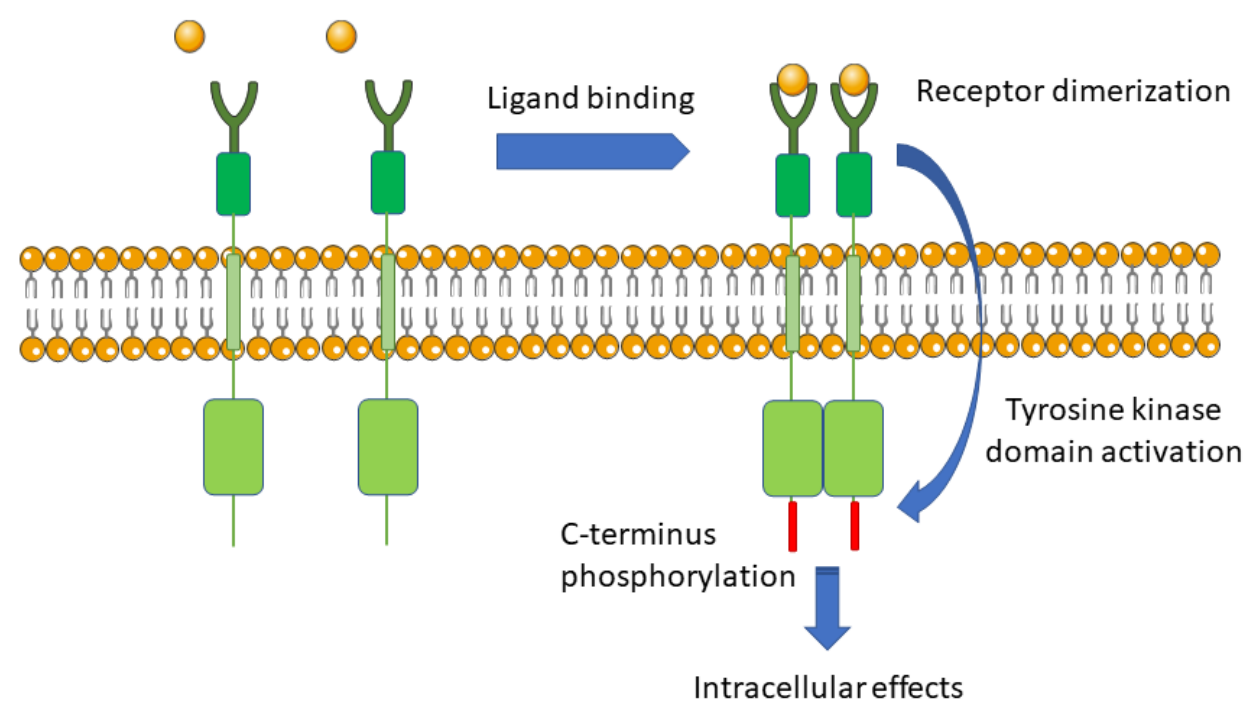

Figure 2. The schematic mechanism of signal transduction via the membrane receptor [141].

Based on the number and nature of transmembrane domains, three classes of membrane receptors are distinguished [141]. Class I contains receptors comprised of several protein subunits, each repeatedly pierces the cell membrane, that together form an ion channel, such as ionotropic receptors (IRs) [142]. Class II consists of receptors composed of one peptide chain, which penetrates the cell membrane several times; for example, G proteincoupled receptor (GPCR) penetrates the membrane seven times [143]. Class III includes receptors that penetrate the cell membrane once. The latter may have a monomeric (receptors of most growth factors) or oligomeric structure (insulin and most cytokine receptors). Class III receptors have the amino acid sequence with enzymatic activity (e.g., non-receptor tyrosine kinases [144] or contain the so-called death domain (DD) [145] (Figure 3)).

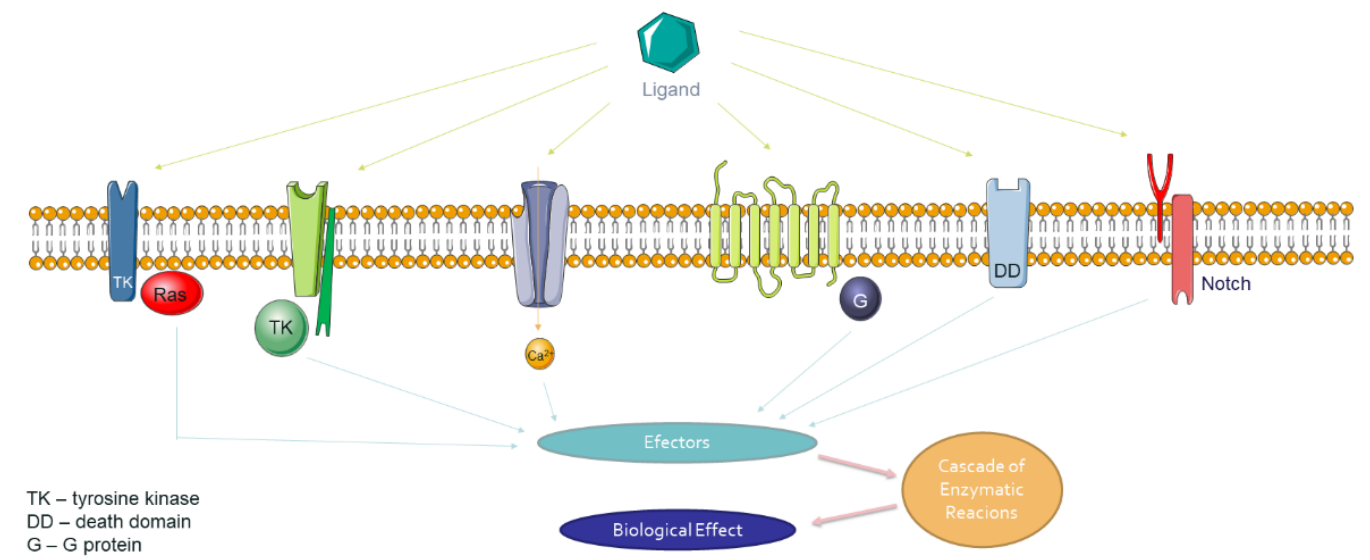

Figure 3. The variety of the signal transduction mechanisms via different membrane receptors [142-145].

Ligand-activated receptors transmit signals into the cell by activating signaling pathways that ultimately affect cytosolic machinery or nuclear transcriptional programs or directly translocating the nucleus to regulate transcription. The abundance of chemical signals forces the cells to recognize and correctly interpret them by much more diverse information carriers. The proper cellular response selectivity toward the stimulus and specificity of the achieved response is regulated by receptor proteins that can bind to excitation signal-bearing molecules, and at the same time, transmit this excitation deep into the cell, up to executive systems called effectors [141]. 


\subsection{Reaction Required and Amplification Mechanism}

One of the key mechanisms that control signal transmission by receptors is exchanging the information, referred to as cross-talk. There are different types of interaction between intracellular signaling pathways: phosphorylation of receptors and regulatory proteins by kinases [146], the interaction of intracellular signal transduction pathways [147], effects on intracellular calcium release [148], heterooligomerization of various receptors of the same family of ligands [149]. For example, the signaling via kinase-associated receptors is organized into multiple feedback mechanisms to confirm an appropriate transmitter level. Therefore, many tyrosine kinases and cytokine receptors bind protein tyrosine phosphatases (PTPs), including SHP1 and SHP2, that contain Src-homology 2 (SH2) domains [150]. Thus phosphorylation/dephosphorylation cycles PTPs modulate signaling quantitatively as well as qualitatively. Another example of cross - talk is the heterotrimeric $\mathrm{G}$ protein cascades Rho guanine nucleotide exchange factors (RhoGEFs), which can serve as the direct downstream effectors of heterotrimeric G proteins [151]. It was postulated that RAS signaling is essentially involved in the switch from tumor-suppressive to tumor-promoting functions of the TGF- $\beta$ family, leading to enhanced cancer growth and metastatic dissemination of primary tumors [152]. Extensive cross-talk between the different pathways activated upon platelet-derived growth factor (PDGF) stimulation was observed. Mendelson et al. noted triggering a metalloproteinase-dependent cross-talk between the PDGFR $\beta$ and the epidermal growth factor receptor (EGFR)/ERK1/2 signaling axis and indicated the involvement of metalloproteinase ADAM17 upon activation of the PDGFR $\beta$ [153].

\subsection{Participation of Integral Membrane Receptors in the Pathological Metabolic Pathway and Targeted Therapy}

Membrane receptors are responsible for the precise reading and transmission of information from ligands to effectors, which activate metabolic pathways. Each modulation of receptors, e.g., genetic defect, may change information transfer and activate different metabolic pathways. Much evidence indicates that receptor dysfunction leads to various diseases, mainly tumors [154]. The observation that overexpression of many integral membrane receptors is common in different cancers became the basis for developing new anticancer therapies based on the inhibition of membrane receptors. Numerous antagonists were developed, including inhibitory antibodies, ligand traps, and low-molecular-weight kinase inhibitors, for use in targeted therapies, which is very promising in treating cancer without side effects $[155,156]$. Many of these antagonists are now being applied in clinical treatment or undergoing clinical trials. The serine/threonine kinase and tyrosine kinase receptors often transmit growth inhibition and apoptotic pathways and have tumor-suppressive effects [157-160].

Due to the fact that overactivity of receptor tyrosine kinases (RTKs) is related to developing various malignancies, we focus on their dysfunctions, ways of modulation, and potential application in targeted therapies. RTKs have a high affinity for many polypeptide growth factors, cytokines, and hormones. Modulation or dysregulation of this receptor leads to developing numerous diseases, including cancer and others, characterized by excessive proliferation of cells, inflammatory and fibrotic conditions [157-160].

Platelet-derived growth factor receptors (PDGFRs) belong to a subfamily of human RTKs. Different dimeric isoforms of the ligand induce the formation of different dimeric complexes of PDGF $\alpha$ and PDGF $\beta$ receptors. Point mutations in Kit and Alpha (PDGFRa) were found in gastrointestinal stromal tumors (GISTs). Moreover, patients with familial GIST syndrome have constitutional KIT/PDGFRA mutations [161]. The translocated kinase domains of PDGFRs and fibroblast growth factor receptors (FGFRs) can act in the cytoplasm as fusion proteins with constitutive activity characteristic of several rare leukemias [162]. Amplification of the ERBB2 gene was found in 20\% of breast cancer cases and a mutated version of the epidermal growth factor receptor (EGFR) gene in $30 \%$ of glioblastomas [119,163]. 
The development of targeted therapies has recently become a crucial research goal. Many small-molecule inhibitors such as lapatinib, neratinib, and tucatinib were used for treating cancer caused by the mutations in RTKs [164]. These inhibitors precisely join the ATP-binding pocket of the intracellular tyrosine kinase domain [155]. Another strategy involves using monoclonal antibodies that inhibit RTK activation. This is exemplified by applying cetuximab in lung cancer, panitumumab in colon cancer, cetuximab in head and neck cancer, or trastuzumab and pertuzumab in breast cancer [165-168].

Some currently applied strategies specifically disturb oncologically active cells by targeting surface receptors and endogenous signaling molecules. The dysfunction of the ErbB2 (HER2) receptor plays a key role in breast cancer pathogenesis. For this reason, HER2 is an important molecular target for researchers. Some antibodies directed against the growth factor receptors HER2 and EGFr were approached [163]. Although HER2+ breast cancers grow quicker and are more invasive than other types, thanks to applying the antibodies directed against HER2 receptors, they are generally approachable to anti-HER2 therapy, which significantly enhances the prognosis $[163,169]$.

\section{Modulation of Cell Membrane Lipidomics}

Lipidomics is a complete set of lipid variants and their biological functions in relation to the expression of proteins responsible for lipid metabolism and their functions. Membrane lipids are essential elements of the cell membrane that determine many cytophysiological processes [170]. The growing understanding of the lipid structure of biological membranes and changes in their properties in various diseases initiated the development of therapies aimed at membrane modification. Therapeutic strategies may involve direct interference with the composition of membrane lipids, which determines the activity of transmembrane proteins and modifies the organization of membrane microdomains, which are involved in transmitting cellular signals [3]. They may also concern changes in the activity of membrane-related enzymes or modulation of gene expression of enzymes influencing lipid composition. Under the influence of phospholipid composition changes and the length and number of double bonds of esterified fatty acid acyls, lipids in the membranes temporarily change their order. There is a liquid-disordered (Ld) phase, where lipid packing is the loosest, and lateral diffusion and lipid rotation are frequent, and a liquid-ordered (Lo) phase, where the lateral lipid diffusion is maintained, but rotation around the long axis of the alkyl chain is significantly limited [171,172]. Such an organization of lipids occurs in membrane lipid microdomains, called lipid rafts, high in cholesterol [173].

The lipid profile analysis of normal and neoplastic cell membranes shows significant differences in the lipid composition. Breast cancer cells have higher cholesterol content compared to normal cells [174]. Neoplastic cell membranes also show disturbances in the ratio of phosphatidylethanolamine (PE) to sphingomyelin (SM) [175]. Lipid mobility is important in the lipid-protein interaction, which is largely dependent on the cholesterol and sphingomyelin content in the raft microdomains [2]. Studies conducted on artificial membranes indicated that daunorubicin by binding to phospholipids reduces the microdomains with hexagonal lipid organization, which disrupts the lipid-membrane protein interaction, and ultimately modifies cell signaling and vesicular transport [176]. Furthermore, 2-hydroxyoleic acid effectively reduces the lipid order in the membrane by stimulating sphingomyelin synthase and increasing the content of sphingomyelin in the membrane of lung cancer, leukemia, and glioma cells, while the lipid structure of normal cells remains unchanged [175].

Barceló-Coblijn et al. indicated that with an increase of the SM:PE ratio, the MAPK kinase pathway is inactivated in tumor cells [177]. Changes in the lipid phase in membranes can be achieved using derivatives of polyunsaturated fatty acids (PUFA). It was shown that increasing the amount of unsaturated fatty acids reduces the Lo/Ld phase ratio by almost $10 \%$ and reorganizes lipid microdomains $[178,179]$. Siddiqui et al. demonstrated that the combination of propofol with PUFA reduces migration and adhesion of breast 
cancer cells and increases cell apoptosis by about $40 \%$ [180]. One of the approaches in anticancer therapy is to increase the $\mathrm{Ld}$ phase of the membrane. It is possible by applying molecules such as alkylphosphocholine (APC), in which the glycerol backbone was removed [181,182]. Such kinds of molecules include miltefosine, perifosine, and euphrosine [183,184]. Van der Luit et al. demonstrated that SM is necessary for APC binding in rafts, and among alkylphosphocholines, edelfosine most strongly inhibits phospholipid synthesis and induces apoptosis in leukemic cells. The mechanism of APC derivatives is most likely based on the inhibition of phosphatidylcholine biosynthesis in the ER [185]. As a result of increasing the number of ceramides in the membrane, the disruption of calcium ions homeostasis occurs, followed by activation of apoptosis and inhibition of the Ras/Raf/MAPK/ERK PI3K/Akt proliferative signaling pathways [186].

Modifications of membrane lipids may include direct interference with the lipid composition, which determines transmembrane protein activity. They may also include changes in the activity of enzymes associated with membranes or modulating gene expression of enzymes affecting lipid composition. The membrane modifications lead to a change in the lipid-protein and protein-protein interactions; thus, the signaling pathways determining tumorigenesis can be inhibited [183,187].

\section{Electroporation}

Short high-voltage electric pulses modify lipid bilayer structure and induce the creation of temporal aqueous pores in a cell membrane. The technique widely known as electroporation (or pulses electric field-PEF) increases cell membrane permeability and allows for transmembrane transport of different molecules. It is used in many fields such as medicine, biotechnology, or food technology. The size and number of pores depend on the electric pulse parameters (duration, amplitude, shape, number of pulses, etc.) [188]. After application of PEFs, the changes induced depend on the intensity of the applied electric fields and can be either reversible (cells recover their integrity) or irreversible (IRE) when the cells turn necrotic. In accordance with the duration of pulses, the three main types of electroporation are discerned, i.e., nanosecond (nsPEF), microsecond ( $\mu \mathrm{sPEF),}$ and milisecond electroporation (msPEF) [189]. The range of electric field generated during the microsecond and millisecond PEF is between 0.1 to $2 \mathrm{kV} / \mathrm{cm}$, while nanosecond PEF uses electric pulses strength above $10 \mathrm{kV} / \mathrm{cm}$. In this chapter, we focus on different modifications of outer and inner cell membranes caused by PEF.

\subsection{The Aqueous Pore Formation}

In natural physiological conditions, eukaryotic cells maintain resting transmembrane voltage (TMV) of -40 to $-70 \mathrm{mV}$ between the inner and outer sides of the membrane. The composition of pumps and ion channels is responsible for TMV regulation. An exposition of cells to external electric pulses generates induced-TMV, which may dramatically exceed the ranges of resting TMV and induce structural changes in molecule composition. The type of PEF determines the size and number of pores-nsPEF creates approximately three times more pores compared to the micro- and millisecond), but simultaneously pore diameters are smaller in case of exposure to nsPEF than to longer pulses [190,191]. The research showed that microsecond electroporation affected TMV of the plasma membrane and endoplasmic reticulum membrane, while application of nsPEF impacted plasma membrane, nuclear membrane, endoplasmic reticulum membrane, inner and outer mitochondrial membrane [190]. Molecular modeling, as well as empirical studies, are consistent with TMV-mediated aqueous pore creation. As a result of PEF application to both sides of the phospholipid bilayer, the so-called water fingers or water defects are formed, grown across the hydrophobic width, and the hydrophilic groups of phospholipid bilayer are directed toward water molecules. Pores extend and fill with water allowing the entrance of other ions and molecules such as genes or drugs [189,192]. 


\subsection{Effects of The Electric Field on Oxidative Stress}

Many years ago, it was noticed that the properties of cell membranes and lipid bilayers could be altered by exposure to electric pulses due to oxidation of their lipid constituents [193-195]. Oxidative stress directly impacts the physical properties of cell membranes and therefore plays a vital role in the electroporation process [196]. The imbalance between the generation and the removal of reactive oxygen species in the body is known as oxidative stress. Reactive oxygen species (ROS) are chemical compounds that can participate in chemical reactions, containing oxygen atoms with an unpaired electron or bonds between two oxygen atoms in their structure. Oxygen is several times more soluble in organic solvents than in water. ROS can arise as a result of ionizing radiation, ultraviolet radiation, ultrasounds, photosensitizers, xenobiotics. The most reactive but short-lived oxygen species include hydroxyl radical, hydroperoxide radical, and superoxide anion radical. Reactive oxygen species with bonds between two oxygen atoms include singlet oxygen, hydrogen peroxide, and ozone [197-200]. The imbalance in the removal of reactive oxygen species by the body due to various pathogens or external factors causes an increase in free radicals. ROS cause damage to cell organelles: the cell membrane, mitochondria, Golgi apparatus, endoplasmic reticulum, lysosomes, and the cell nucleus [197]. Free radicals target proteins (aggregation, oxidation, phosphorylation, dephosphorylation, denaturation), lipids (peroxidation), carbohydrates, and nucleic acids. Changes in the structure of these compounds lead to mutations and cytotoxic effects that affect cell dysfunction $[197,201]$. The relationship between the use of nanosecond pulses $[202,203]$ and conventional electroporation [204] in the presence of excess reactive oxygen species and initiation of apoptosis may lead to an improvement in the efficiency of electroporation and electropermeabilization procedures [205]. The use of millisecond pulses during electropermeabilization produces reactive oxygen species. The increase in oxidative stress was observed when reversible electropermeabilization was applied. Irreversible electropermeabilization disrupted cell membranes, which inhibited the increase in oxidative stress. On the other hand, applying a series of short microsecond pulses caused a decrease in cell survival, which was not related to an increase in oxidative stress $[195,206]$.

\subsection{Effects of the Electric Field on Lipid Peroxidation}

Lipid peroxidation (LPO) is a free radical oxidation process of unsaturated fatty acids or lipids from which the peroxides of these compounds are formed $[197,207,208]$. There are three stages of the lipid peroxidation process. The first step consists of detaching the hydrogen atom from the unsaturated fatty acid molecule, which is part of phospholipids that are easily oxidized by free radicals [197]. LPO can be initiated by hydroxyl, peroxide, alkoxy, or alkyl radical, as well as ozone, nitrogen oxide, and dioxide, or sulfur dioxide and hypochlorite [209]. In the second step, free alkyl radicals react with oxygen to form peroxide free radicals. In turn, these radicals can detach hydrogen atoms from successive unsaturated fatty acids, which in turn leads to further reactions with unsaturated fatty acid molecules. This step is repeated many times. In the third step, reactions occur between two free alkyl or peroxide radicals or two different ones nearby [207].

The exposure of cells to electrical pulses can cause LPO, which was confirmed in plant cells [195,210], bacteria [211,212], and mammalian cells [193,195,213]. LPO induced through electroporation causes growth of membrane permeability and fluidity [195]. Studies including micro- and millisecond pulses demonstrated that electric pulses provoke the generation of reactive oxygen species (ROS) and intense oxidative damage of unsaturated lipids in cell membranes. Free radicals formed during lipid oxidation can react with other components of cell membranes, e.g., proteins. The end products of LPO may be aldehydes, as was confirmed by measuring the concentration of malondialdehyde (MDA) [193], hydroxy-aldehydes $[197,208]$, and hydrogen peroxide $[214,215]$ by detection of superoxide anion radicals $[189,194]$.

Many studies show that the use of appropriate electroporation protocols induces the formation of lipid hydroperoxides in cell membranes $[207,216]$. It was observed that 
electrical pulses generate reactive oxygen species and ROS concentration and increase with electric field intensity [193-195,213,217], pulse duration, and the number of pulses [194]. It was found that there is a correlation with cell membrane permeability $[194,195,213]$, membrane resealing time [194], and cell damage [189,193,194]. Studies show that a controlled increase of LPO in cell membranes prior to electroporation increases membrane permeability without significantly affecting cell survival, which may increase the efficiency of electropermeabilization [205].

\subsection{Effects of Electric Pulses on Membrane Proteins}

There is a hypothesis of denaturation of transmembrane transport proteins during exposure to electric pulses. Electropermeabilization can generate sufficient heating membrane proteins for denaturation. Cell membrane takes up to ten minutes to excise or replace denatured proteins from the membrane and regain impermeability $[218,219]$. The available results confirmed that electroporation of sub-microsecond duration and high amplitudes could affect the conductivity of transmembrane protein structures, i.e., voltage-gated $\mathrm{Ca}^{2+}$ and $\mathrm{Na}^{+}$channels [220-226].

\subsection{Cytoskeleton Remodeling after PEF}

In recent years, the influence of PEF on cytoskeleton structure has been studied extensively. A cytoskeleton is composed of actin, microtubules-tubulin, and intermediate filaments, mainly providing cell stability and cell-cell contact, proliferation, migration, and differentiation $[227,228]$. In physiological conditions, actin fibers form stress fibers, filopodia, and lamellipodia, determining cell shape, proper tension and flexibility, extraand intracellular transport, contact between cells, and locomotion. Actin is strictly linked with the cell membrane and interacts with the phospholipid bilayer modification caused by, e.g., PEF. Studies show that electroporation affects ruffled membranes and actin bundles accumulated on the cell surface and periphery [229-231]. Changes in cell shape or rounded and swollen cells are often observed after PEF application. The most frequent changes in actin triggered by PEF include shortening, fragmentation, and fiber density loss. Analyses of cytoskeleton disruption also revealed a decline of membrane stiffness and impaired attachment of F-actin fibers to the cell membrane [232]. The electric pulses permeabilize other cell components causing enzyme or / and ions release (e.g., caspase, $\mathrm{Ca}^{2+}$ ), which may lead to cytoskeleton disorganization [233]. While nsPEF causes only membrane ruffling, which disappeared after $4 \mathrm{~min}(60 \mathrm{~ns}, 60 \mathrm{kV} / \mathrm{cm}, 1$ impulse). However, longer pulses (100 $\mathrm{ns}, 20 \mathrm{kV} / \mathrm{cm}, 20$ impulses) initiate shortening and oligomerization of actin fibers, and the cytoskeleton recovery is achieved approximately after $60 \mathrm{~min}[230,234]$. The increase of zyxin expression and stress fiber tension was found in normal muscle cells $\mathrm{C} 2 \mathrm{C} 12$ after $\mu \mathrm{SPEF}$ application. However, the actin cytoskeleton and zyxin reduction disruption was observed after applying the same PEF parameters [235]. Millisecond PEF $(5 \mathrm{~ms}, 0.4 \mathrm{kV} / \mathrm{cm}$, 8 pulses) causes actin stress fiber disruption even after membrane resealing [236].

Microtubules (MTs) are stiff, tube-like, and localize around the nucleus and radiate to the edge of the cell membrane [237]. PEF application induces a short-term reduction of microtubule network density and depolarization [238,239]. Likewise, $\mu$ sPEF causes tubulin depolarization and fragmentation, which are recovered after a few hours [240]. Thompson et al. and Carr et al. demonstrated tubulin depolarization and fragmentation after nsPEF. In addition, microtubules accumulated nearby the cell membrane and reduced the network density. Studies indicate numerous ruptures of tubulin filaments [229,241].

Intermediate filament (IF) is the third element of the cytoskeleton and the most insoluble part of the cell components. It creates fibers with high tensile strength and is responsible for stabilizing cells, cell organelles and creating specific junctions. IFs partitioned by their structure are classified into four groups: vimentin filaments, keratin filaments, neurofilaments, and nuclear lamins [236,242]. The studies under PEF interaction with intermediated filaments are insufficient; however, some of them demonstrated perinuclear collapse of IF and disruption of nuclear lamins after nsPEF $[238,242,243]$. Despite the increasing number 
of PEF effects on cell structure, many cytoskeleton disruption mechanisms still require an experimental solution.

\subsection{Clinical Potential (Aspect) of Electroporation}

Over the years, electroporation procedures have reached a major role in clinical trials in human and veterinary oncology. Application of electric pulses allows to overcome barrier of cell membrane and transport different molecules into cellular compartments. In oncology, electroporation combined with chemotherapeutics (bleomycin, cisplatin) injection called electrochemotherapy (ECT) results in several facilities: increase of drug cytotoxicity, low drug concentration, significant reduction of tumor size, immune system stimulation and reduction of side effects [244]. Successful ECT clinical results demonstrating effectiveness and safety of the method have become a foundation of European Standard Operating Procedures on Electrochemotherapy (ESOPE) with Cliniporator. Currently, ECT is used against primary tumors and metastasis in over 130 European oncology centers and also in veterinary oncology [245].

Nonthermal irreversible electroporation (NTIRE) uses extremely high electric pulses to cell or tissue ablation. Ones of many advantages of NTIR are: minimal invasive surgical procedure, tissue architecture preservation and scaring reduction [246].

DNA vaccination and gene transfer (GET) are another medical application of electroporation. GET is used in cancer treatment by delivering immunomodulatory (e.g., interleukins) or vasculature tumor targeted genes. There are number of reports of IL-12 and AMEP delivery by GET for treatment of human cutaneous melanoma nodules, horses sarcoids, and primary dog tumors [247]. Moreover, GET significantly increases the DNA vaccination effectiveness, while introduction of DNA and RNA into cells is explored in regenerative medicine [248].

\section{Sonoporation}

Over the past few decades, research has revealed the potential to incorporate physical techniques into anticancer therapies to deliver impermeable compounds into the cell interior. One of the most promising is the use of ultrasounds (US) which can stimulate pore formation in the cell membrane structure, referred to as sonoporation. Except for externally delivered ultrasounds, microbubbles are the second component incorporated into this technique. Although not mandatory, they are frequently used together with ultrasounds to increase the sonoporation efficiency through cavitation [249-251]. Sonoporation is based on the propagation of ultrasounds through the media and tissues exerting direct radiation and secondary forces resulting from the interaction between the tissue, surrounding media, and microbubbles [252]. Consequently, the main factors contributing to the effectiveness of sonoporation-based therapies include acoustical driving parameters, properties of the environment surrounding the targeted tissue, and additionally introduced cavitation agents [252]. Lentacker et al. identified three main ultrasound settings enabling sonoporation: (i) application of ultrasounds without additional cavitation agents (ii) stable cavitation exerted by low-intensity ultrasound (iii) inertial cavitation evoked by high-intensity ultrasound [253]. The above approaches may provide pore formation through various mechanisms, as shown in Figure 4.

Among the mechanisms triggered by ultrasounds, the most significant role is attributed to the oscillation of cavitation agents (Figure 4A) and shear stress generated by the medium movement around cavitation nuclei (Figure 4B). The gas inside a bubble differs in impedance from surrounding tissues; hence, it shrinks and expands in response to the negative or positive ultrasound phase [253-256]. The ultrafast coupled microscopy and realtime confocal microscopy studies revealed a strong correlation between microsecond-scale bubble oscillations and second-to-minute-scale macromolecule diffusion through transient pores formed in the plasma membrane [257]. Although not as prominent, the increased macromolecule uptake was also observed without any additional microbubbles [258-260]. This effect was attributed to cavitation caused by the gas bodies present in a medium or 
acoustic streaming and secondary shear forces $[253,261,262]$. Introducing microbubbles as cavitation nuclei enhances acoustic energy absorption and lowers the cavitation threshold, thereby intensifying the cavitation-induced bioeffects [263-265]. Currently, microbubbles of different sizes, gas filing, and shell composition are commercially available [266].

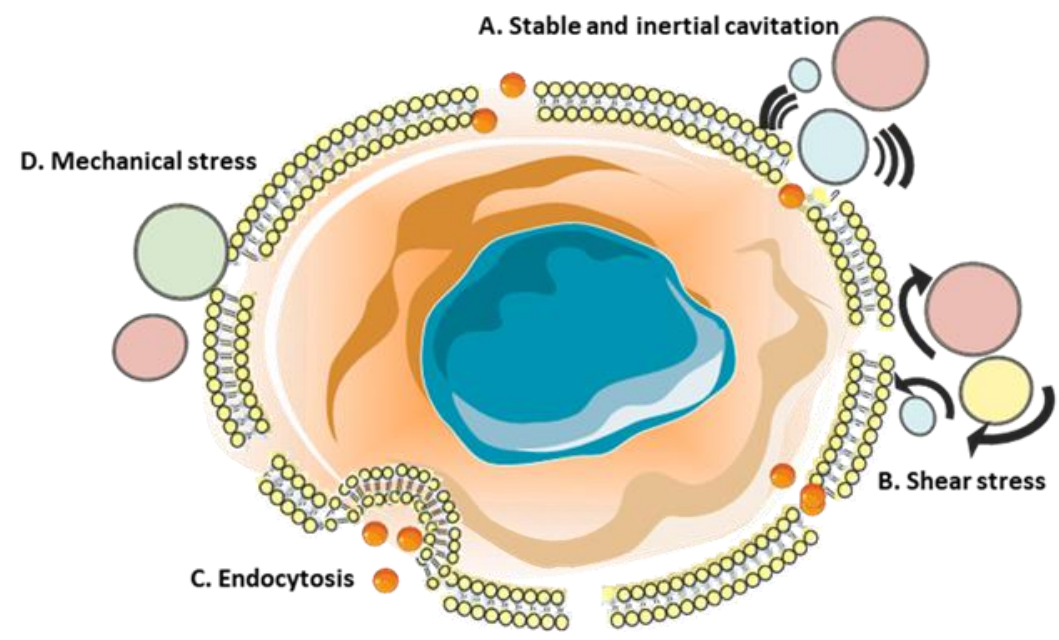

Figure 4. Mechanisms involved in sonoporation of the cell membrane after ultrasounds application: (A) cavitation of microbubbles and gas bodies in surrounding medium; (B) shear stress evoked by acoustic streaming and medium flow during cavitation; (C) endocytosis; (D) mechanical stress triggered by the cavitating agents [253].

\subsection{In Vitro Research on Sonoporation}

Extensive research has been conducted since the very first application of ultrasounds in vitro. Nonetheless, due to high variability between study parameters (such as ultrasound frequency, intensity, pressure, presence of cavitation nuclei, size, and composition), it is exceptionally difficult to compare their results. Most of the studies use high-frequency ultrasounds (above $1 \mathrm{MHz}$ ), as these are characteristic for therapeutic US transducers (1 to $3 \mathrm{MHz}$ ) and diagnostic US transducers ( 3 to $18 \mathrm{MHz}$ ). However, currently, more and more studies also apply low-frequency ultrasound transducers (below $500 \mathrm{kHz}$ ) [267]. While high-frequency and high-intensity US leads to less-controllable effects such as heating [268], the effectiveness of low-intensity treatments is often determined by non-thermal effects such as acoustic cavitation and biological signaling [269]. Importantly, using lower frequencies may also provide excessive cellular damage due to the erosive effects of highly energetic inertial cavitation [270]. Both high- and low-frequency ultrasounds have been shown to increase the intracellular transport of fluorescent dyes [271-273], genes [274-276], and chemotherapeutic drugs [275-278]. The last one demonstrates the great potential of this technique as an anticancer treatment. Up to now, the efficacy of ultrasound as an enhanced delivery system was proven in various cancer models in vitro, including prostate cancer [273], retinoblastoma [278], squamous carcinoma [279], breast cancer [280], ovarian and liver tumors [281]. The efficacy of sonoporation depends on cell type, hence optimizing the exposure parameters can safely and efficiently increase the cell membrane permeability [281].

\subsection{Preclinical Studies on Sonoporation}

In vitro studies demonstrated the great potential of sonoporation as an anticancer technique. However, these results cannot be directly translated into clinical practice, as the conditions are very different from the actual tumor environment. Among the key factors influencing the effectiveness of sonoporation that are difficult or impossible to mirror in vitro, the following should be mentioned: viscoelasticity of surrounding media and tissue, the number of available cavitation nuclei, the distribution of the ultrasound wave, and finally, the organism immunological response. Regardless of these differences, sonoporation was found to be effective in xenograft models of human epidermoid and human 
pancreatic carcinoma [282,283], prostate cancer [284], and breast tumors [285]. Especially encouraging was the impact of ultrasounds on improving drug targeting of tumors with low enhanced permeability and retention effect [282]. For that reason, sonoporation is of particular interest in therapies targeting pancreatic cancer. In preclinical study gemcitabine therapy combined with sonoporation significantly impeded tumor development in the orthotopic xenograft model of human pancreatic cancer [283].

\subsection{Clinical Application of Sonoporation in Oncology}

Sonoporation similarly to electroporation can be implemented in the cancer treatment either as a measure for tumor ablation or to evoke increased tumor permeability to anticancer agents. Sonoporation is not targeted at specific cellular mechanisms but rather at producing a biological effect through a generation of physical forces acting on cells. Therefore, its efficacy is much less dependent on the histological type of a tumor compared to non-physical treatment methods.

The most common clinical application of ultrasounds in the context of cancer therapy is high-intensity focused ultrasound (HIFU), which found application in the treatment of various tumors. Some of them, such as ablation of hepatic and breast tumors, are not approved by Food and Drug Administration (FDA), while some are already FDA-approved these include ablation of uterine leiomyomas, ablation of bone metastasis, ablation of prostate cancer, and neurological applications [286]. Extensive studies were carried out using the extracorporeal HIFU device to treat patients with advanced liver cancer, resulting in tumor ablation, palliation, and improved overall survival [287-290]. Early clinical safety studies were performed on patients with advanced renal tumors suggesting the safety and feasibility of HIFU in this tumor [291]. This technique found application also for the treatment of prostate carcinoma and was proven to be effective as focal therapy for nonmetastatic prostate cancer. However, complications were also reported following HIFU, including urinary retention, incontinence, urinary infection, impotence, chronic pain, rectal and anal fistulas, and burns [287,292]. Ultrasound, microbubbles, and chemotherapy with gemcitabine were safely combined in Phase I of the clinical trial in inoperable pancreatic cancer patients [267]. In the study, sonoporation improved the clinical efficacy of gemcitabine, prolonged the quality of life, and extended survival in patients with pancreatic ductal adenocarcinoma (from 8.9 to 17.6 months, $\mathrm{n}=10$ ) without any additional toxicity.

Although promising, current trials demonstrate that ultrasound application also carries the risk of occasionally severe side effects. Miller et al. highlighted several safety factors that still need to be addressed when using sonoporation to achieve the optimum benefit to risk ratio, namely operator and patient safety, quality assurance, accumulating biological effect, risk-benefit ratio, and safety research [293]. Depending on the ultrasound settings, various effects may be evoked in tumors, starting from local permeabilization for targeted drug delivery to extensive tumor destruction by high-frequency and highintensity ultrasounds. Therefore, there is a considerable need to introduce universal and international operating procedures allowing for a safe and controllable sonoporation application in clinical practice.

\section{Gravitational Forces Affecting Biomembranes}

In recent years, we have witnessed a rapid development of space sciences, which provided us with a plethora of medical and biological challenges concerning life existence and survival in space. Whereas outer space is full of hazardous factors dangerous for man, one of them, namely unnatural gravity-micro- and hyper-gravity-affects cells in a fascinating way leading to altered human physiology. Microgravity is defined as a state where objects have a reduced weight, which is mostly associated with spaceflight. On the other hand, hyper-gravity is a phenomenon mainly experienced during accelerations accompanying spaceship launch, when the gravity force is higher than that on the surface of the Earth [294]. Thus, gravity-related research is a new tool for understanding cancer cell biology, which may help us detect novel molecular targets for future tumor treatment [295-297]. The aim of such 
experiments is to widen current knowledge of cancer treatment in altered gravity and shed new insight on the implementation of gravity-related therapies in medicine in the future. Gravity-based studies constitute an excellent initial step toward enhancing our understanding of the relationship between cellular resistance to chemotherapy and the response to various gravitational stimuli. Going further, the exposure to altered gravity environment by the appropriate combination with chemotherapeutic protocols may become a new agent used in cancer treatment which will allow its medical application in the future.

Until now, a number of studies were carried out under simulated conditions of unnatural gravity using ground-based facilities such as clinostats, random positioning machines, bioreactors, and parabolic flights for simulated microgravity (s $\mu g$ ) research [298-300], and well-designed centrifuges for hyper-gravity experiments [301,302]. Some real microgravity $(\mu g)$ investigations were conducted in space on the International Space Station or onboard sounding rockets [303]. Both micro- and hyper-gravity was shown to affect various cellular processes such as gene expression [304,305], proliferation [306], differentiation [307-312], autophagy [310,313,314] and cell death [305,310,315]. Although the mechanism of cellular graviperception remains unclear [316,317], previous studies suggested an essential role of the cytoskeleton [305], adhesive molecules [318], and cell membrane mechanoreceptors in that process. It is known that the reorganization of cytoskeletal fibers caused by mechanical forces such as altered gravity strongly alters cell functioning [294,319,320]. This phenomenon results in characteristic changes to cell morphology such as the rounded shape of cells, the presence of membrane blebbing [318] as well as the formation of complex 3D spheroid structures [300], or altered functioning of filopodia and lamellipodia [319], which may lead to the reduced migration observed under hyper-gravity [306]. Additionally, there is an interesting connection between cytoskeleton and multidrug resistance (MDR) proteins. Cytoskeletal fibers influence the activity of MDR proteins located in lipid rafts without in gene expression [321]. At the same time, hyper-gravity is thought to affect cell membrane architecture by lipid rafts and its interactions with cytoskeleton [322] and, thus, modify drug sensitivity. Moreover, it was revealed that cells cultured under hyper-gravity display enriched cell membranes with extracellular matrix proteins [323]. Furthermore, this phenomenon was reported to inhibit metastasis and drug resistance of cancer cells [324].

A study by Janmaleki et al. revealed that exposure to $s \mu g$ caused a notable drop in cell stiffness and cell membrane viscosity [325]. On the other hand, membrane viscosity affects diffusion-controlled reactions [326] and regulates protein movement within the plasma membrane and cytoplasm [327,328], which alters signaling pathways and gene expression. Furthermore, membrane fluidity depends on gravity loading [329-331], which most likely affects pharmacodynamics and drug uptake under unnatural gravity conditions [330]. In light of the above findings, both micro- and hyper-gravity may regulate cell membrane biophysical properties and affect cell functioning on a genetic and proteomic level (Figure 5).

Further research should consider the link between cell membrane, cytoskeleton, and MDR-related proteins and possible molecular pathways proving interactions between them. 


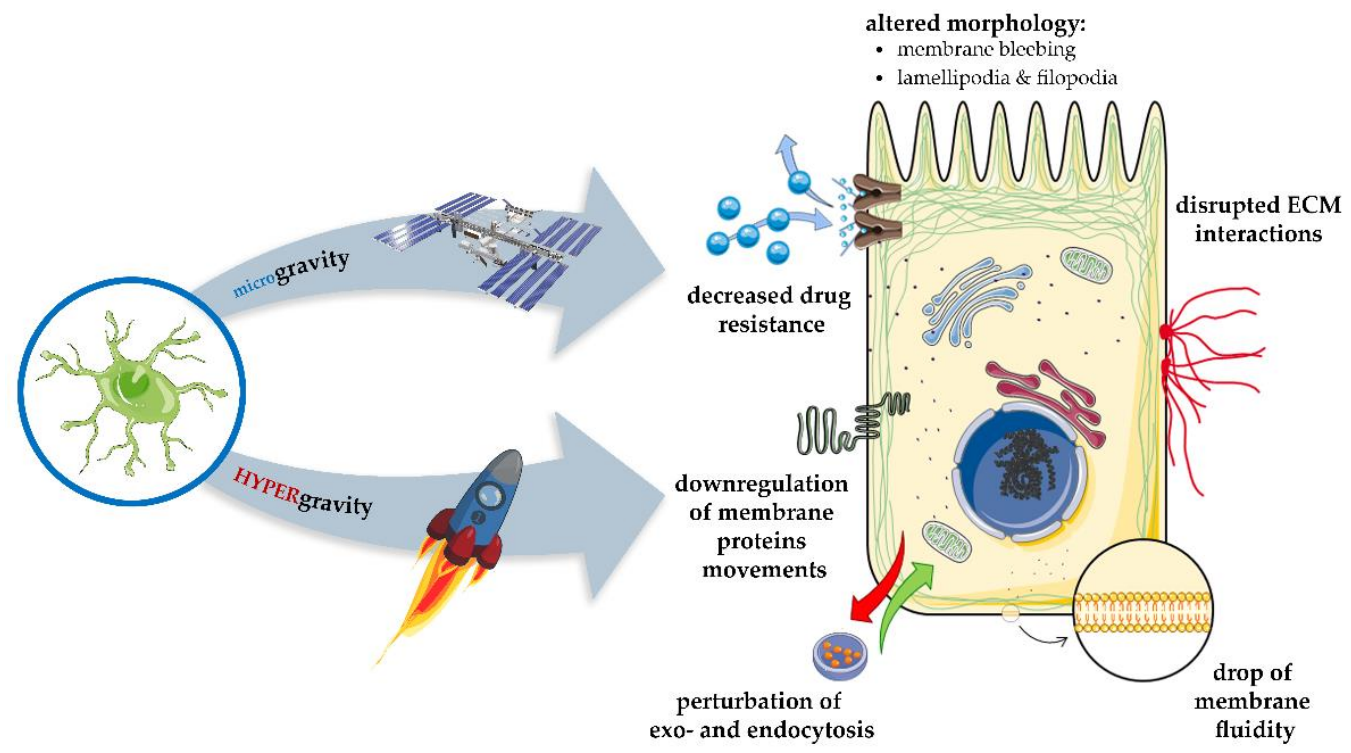

Figure 5. Modification of cell membrane by micro- and hyper-gravity. Altered gravity is known to affect biomembranes on many levels. First, it influences on the morphology of cell by creating membrane blebbing and affects functioning of lamellipodia and filopodia. Furthermore, unnatural gravity alter membrane fluidity and movements of transmembrane proteins leading to decreased multidrug resistance and disruption of exo- and endo-cytosis. This figure was prepared using Servier Medical Art, available from www.servier.com/Powerpoint-image-bank.

\section{Conclusions}

The cell membrane is an exceptionally organized and complex cell element responsible for maintaining the cell structure and interacting with the environment. The possibility of manipulating its composition and function is a powerful tool in cancer treatment, both in combination with chemotherapeutic agents and physical membrane modification methods. In Table 1, we have gathered the types of plasma membrane modifications for targeted cancer therapies, which have been described in the review. The cell membrane and its components must be considered key factors in cancer treatment and deserve consideration when developing new therapeutic strategies. However, it should be kept in mind that the choice of an appropriate cell membrane modification strategy depends on the tumor type, location, and stage.

Table 1. Types of plasma membrane modification for targeted cancer therapy.

\begin{tabular}{|c|c|c|c|}
\hline Method & Type of Membrane Modification & Expected Outcomes & Literature \\
\hline MDR modulators & $\begin{array}{c}\text { Translocation of the ABC superfamily } \\
\text { proteins } \\
\text { Decrease in the level of ABC } \\
\text { superfamily proteins } \\
\text { Altered lipid integrity, fluidity or } \\
\text { permeability of cell membrane } \\
\text { Modulation of ABC superfamily } \\
\text { proteins activity }\end{array}$ & $\begin{array}{l}\text { Increase in cellular sensitivity to } \\
\text { anti-cancer drugs/decrease of MDR }\end{array}$ & $\begin{array}{c}{[35]} \\
{[48]} \\
{[52,54,55]} \\
{[31,34,41,47,49-53,56-64]}\end{array}$ \\
\hline $\begin{array}{l}\text { MicroRNAs as regulators of } \\
\text { MDR }\end{array}$ & $\begin{array}{l}\text { Decrease in the level of } A B C \\
\text { superfamily proteins }\end{array}$ & $\begin{array}{l}\text { Increase in cellular sensitivity to } \\
\text { anti-cancer drugs/decrease of MDR }\end{array}$ & [74-87] \\
\hline Modification of IC & $\begin{array}{c}\text { Diminish of IC activity by natural and } \\
\text { synthetic inhibitors } \\
\text { IC inhibition by antibodies } \\
\text { IC expression decrease by siRNA, } \\
\text { miRNA, CRISPR/Cas9 }\end{array}$ & $\begin{array}{l}\text { Alterations in ion efflux/influx; } \\
\text { inhibition of cell proliferation, } \\
\text { motility, and invasiveness; increase } \\
\text { of cell apoptosis and sensitivity for } \\
\text { anticancer drugs }\end{array}$ & $\begin{array}{c}{[106,111,113,116,122]} \\
{[127,128]} \\
{[132-135]}\end{array}$ \\
\hline $\begin{array}{l}\text { Membrane receptors } \\
\text { modulations }\end{array}$ & Inhibition of membrane receptors & $\begin{array}{l}\text { Sensitize cancer cells to } \\
\text { conventional therapy }\end{array}$ & [155-160,164-169] \\
\hline
\end{tabular}


Table 1. Cont.

\begin{tabular}{|c|c|c|c|}
\hline Method & Type of Membrane Modification & Expected Outcomes & Literature \\
\hline $\begin{array}{l}\text { Membrane lipidomics } \\
\text { modulations }\end{array}$ & $\begin{array}{l}\text { Changes in the composition of } \\
\text { membrane lipids } \\
\text { Changes in the activity of } \\
\text { membrane-related enzymes and } \\
\text { signaling pathways }\end{array}$ & $\begin{array}{l}\text { Increased membrane permeability, } \\
\text { decreased drug resistance } \\
\text { Sensitize cancer cells to } \\
\text { conventional therapy }\end{array}$ & $\begin{array}{c}{[3,171-173,175,176,178,179,} \\
181,182,185,186] \\
{[177,186]}\end{array}$ \\
\hline Electroporation & $\begin{array}{l}\text { Induction of pores in the lipid } \\
\text { membrane. } \\
\text { Irreversible pores-membrane disruption }\end{array}$ & $\begin{array}{c}\text { Increased membrane } \\
\text { permeability/cell lysis, delivering } \\
\text { drugs into the cell }\end{array}$ & $\begin{array}{c}{[188-192,195,202-206,220-} \\
225,229-231,233- \\
236,238,239,242,243]\end{array}$ \\
\hline Sonoporation & $\begin{array}{c}\text { Membrane invaginations-pores, } \\
\text { endocytotic vesicles; membrane } \\
\text { disruption }\end{array}$ & $\begin{array}{c}\text { Increased membrane } \\
\text { permeability/cell lysis, delivering } \\
\text { drugs into the cell }\end{array}$ & {$[252,253,268,270]$} \\
\hline Gravitational forces & $\begin{array}{l}\text { Membrane blebbing; drop of membrane } \\
\text { fluidity; disrupted ECM interactions } \\
\text { and membrane proteins movements }\end{array}$ & $\begin{array}{l}\text { Decreased drug resistance; altered } \\
\text { cell morphology }\end{array}$ & {$[294-299]$} \\
\hline
\end{tabular}

Author Contributions: A.C. (Anna Choromańska) prepared Sections 2 and 10 and prepared the work in terms of editing; A.C. (Agnieszka Chwiłkowska) prepared Section 3 and prepared the work in terms of editing; J.K. prepared Section 1 and finally revised the manuscript; D.B. prepared Section 4; N.R. and A.S., they prepared Section 7; O.M. prepared Section 8; A.G.-N. prepared Section 6; D.P. prepared Section 9; J.S. prepared Section 5. All authors have read and agreed to the published version of the manuscript.

Funding: This publication was prepared under the project No. RN-N/1798-420/2020 “Molecular alterations induced by simulated microgravity and their implications to drug resistance of human cancer cells" financed from the funds granted by the Ministry of Science and Higher Education in the "Regional Initiative of Excellence" programme for the years 2019-2022, project number 016/RID/2018/19 the amount of funding 11998121.30 PLN, and partially by the Subsidy of Department of Molecular and Cellular Biology No.: SUB.D260.21.095 by National Science Centre (Poland) within a framework of SONATA BIS 6 (2016/22/E/NZ5/00671; PI: J. Kulbacka).

Institutional Review Board Statement: Not applicable.

Informed Consent Statement: Not applicable.

Data Availability Statement: Data sharing not applicable. No new data were created or analyzed in this study. Data sharing is not applicable to this article.

Acknowledgments: Thanks to Wojciech Szlasa for preparing Figures 2 and 3.

Conflicts of Interest: The authors declare no conflict of interest.

\section{References}

1. Preta, G. New Insights into Targeting Membrane Lipids for Cancer Therapy. Front. Cell Dev. Biol. 2020, 8, 876. [CrossRef]

2. Zalba, S.; Ten Hagen, T.L.M. Cell membrane modulation as adjuvant in cancer therapy. Cancer Treat. Rev. 2017, 52, 48-57. [CrossRef]

3. Szlasa, W.; Zendran, I.; Zalesińska, A.; Tarek, M.; Kulbacka, J. Lipid composition of the cancer cell membrane. J. Bioenerg. Biomembr. 2020, 52, 321-342. [CrossRef]

4. Kojima, K. Molecular aspects of the plasma membrane in tumor cells. Nagoya J. Med. Sci. 1993, 56, 1-18. [PubMed]

5. Nicolson, G.L. Cell Membrane Fluid-Mosaic Structure and Cancer Metastasis. Cancer Res. 2015, 75, 1169-1176. [CrossRef] [PubMed]

6. Rivel, T.; Ramseyer, C.; Yesylevskyy, S. The asymmetry of plasma membranes and their cholesterol content influence the uptake of cisplatin. Sci. Rep. 2019, 9, 5627. [CrossRef]

7. Zhen, X.; Cheng, P.; Pu, K. Recent Advances in Cell Membrane-Camouflaged Nanoparticles for Cancer Phototherapy. Small 2019, 15, e1804105. [CrossRef] [PubMed]

8. Pakhomova, O.N.; Gregory, B.W.; Pakhomov, A.G. Facilitation of electroporative drug uptake and cell killing by electrosensitization. J. Cell. Mol. Med. 2013, 17, 154-159. [CrossRef]

9. Neumann, E.; Kakorin, S. Membrane electroporation: Chemical thermodynamics and flux kinetics revisited and refined. Eur. Biophys. J. 2018, 47, 373-387. [CrossRef] 
10. Lakshmanan, S.; Gupta, G.K.; Avci, P.; Chandran, R.; Sadasivam, M.; Jorge, A.E.S.; Hamblin, M.R. Physical energy for drug delivery; poration, concentration and activation. Adv. Drug Deliv. Rev. 2014, 71, 98-114. [CrossRef]

11. Belyavskaya, N.A. Free and membrane-bound calcium in microgravity and microgravity effects at the membrane level. Adv. Sp. Res. Off. J. Comm. Sp. Res. 1996, 17, 169-177. [CrossRef]

12. Kohn, F.; Hauslage, J.; Hanke, W. Membrane Fluidity Changes, A Basic Mechanism of Interaction of Gravity with Cells? Microgravity Sci. Technol. 2017, 29, 337-342. [CrossRef]

13. Rojas, M.; Donahue, J.P.; Tan, Z.; Lin, Y.Z. Genetic engineering of proteins with cell membrane permeability. Nat. Biotechnol. 1998, 16, 370-375. [CrossRef]

14. Yan, H.; Shao, D.; Lao, Y.-H.; Li, M.; Hu, H.; Leong, K.W. Engineering Cell Membrane-Based Nanotherapeutics to Target Inflammation. Adv. Sci. 2019, 6, 1900605. [CrossRef] [PubMed]

15. Shi, T.; Fan, X.; Wu, Y.; Ma, Q.; Xu, Q.; Xie, X.; Chen, N. Mutation of genes for cell membrane synthesis in Corynebacterium glutamicum causes temperature-sensitive trait and promotes L-glutamate excretion. Biotechnol. Biotechnol. Equip. 2020, 34, 38-47. [CrossRef]

16. Kumar, A.; Jaitak, V. Natural products as multidrug resistance modulators in cancer. Eur. J. Med. Chem. 2019, 176, 268-291. [CrossRef] [PubMed]

17. Minko, T.; Rodriguez-Rodriguez, T.; Pozharov, V. Nanotechnology approaches for personalized treatment of multidrug resistant cancer. Adv. Drug Deliv. Rev. 2013, 65, 1880-1895. [CrossRef]

18. Kartal-Yandim, M.; Adan-Gokbulut, A.; Baran, Y. Molecular mechanisms of drug resistance and its reversal in cancer. Crit. Rev. Biotechnol. 2016, 36, 716-726. [CrossRef]

19. Lehne, G. P-glycoprotein as a drug target in the treatment of multidrug resistant cancer. Curr. Drug Targets 2000, 1, 85-99. [CrossRef]

20. Goldstein, L.J.; Galski, H.; Fojo, A.; Willingham, M.; Lai, S.L.; Gazdar, A.; Pirker, R.; Green, A.; Crist, W.; Brodeur, G.M. Expression of a multidrug resistance gene in human cancers. J. Natl. Cancer Inst. 1989, 81, 116-124. [CrossRef] [PubMed]

21. Luqmani, Y.A. Mechanisms of drug resistance in cancer chemotherapy. Med. Princ. Pract. 2005, 14 (Suppl. 1), 35-48. [CrossRef] [PubMed]

22. Anderson, J.M.; Heindl, L.M.; Bauman, P.A.; Ludi, C.W.; Dalton, W.S.; Cress, A.E. Cytokeratin expression results in a drug-resistant phenotype to six different chemotherapeutic agents. Clin. Cancer Res. 1996, 2, 97-105. [PubMed]

23. Dagogo-Jack, I.; Shaw, A.T. Tumor heterogeneity and resistance to cancer therapies. Nat. Rev. Clin. Oncol. 2017, 15, 81. [CrossRef] [PubMed]

24. Zhitomirsky, B.; Assaraf, Y.G. Lysosomes as mediators of drug resistance in cancer. Drug Resist. Updates 2016, 24, 23-33. [CrossRef]

25. Pfeffer, C.M.; Singh, A.T.K. Apoptosis: A Target for Anticancer Therapy. Int. J. Mol. Sci. 2018, 19, 448. [CrossRef] [PubMed]

26. Montero, A.J.; Jassem, J. Cellular redox pathways as a therapeutic target in the treatment of cancer. Drugs 2011, 71, 1385-1396. [CrossRef]

27. Stavrovskaya, A.A.; Stromskaya, T.P. Transport proteins of the ABC family and multidrug resistance of tumor cells. Biochemistry 2008, 73, 592-604. [CrossRef]

28. Jones, P.M.; George, A.M. Mechanism of ABC transporters: A molecular dynamics simulation of a well characterized nucleotidebinding subunit. Proc. Natl. Acad. Sci. USA 2002, 99, 12639-12644. [CrossRef]

29. Simon, S.M.; Schindler, M. Cell biological mechanisms of multidrug resistance in tumors. Proc. Natl. Acad. Sci. USA 1994, 91, 3497-3504. [CrossRef] [PubMed]

30. Eilers, M.; Roy, U.; Mondal, D. MRP (ABCC) transporters-mediated efflux of anti-HIV drugs, saquinavir and zidovudine, from human endothelial cells. Exp. Biol. Med. 2008, 233, 1149-1160. [CrossRef]

31. Bansal, T.; Jaggi, M.; Khar, R.K.; Talegaonkar, S. Emerging significance of flavonoids as P-glycoprotein inhibitors in cancer chemotherapy. J. Pharm. Pharm. Sci. 2009, 12, 46-78. [CrossRef] [PubMed]

32. Booth, C.L.; Pulaski, L.; Gottesman, M.M.; Pastan, I. Analysis of the properties of the N-terminal nucleotide-binding domain of human P-glycoprotein. Biochemistry 2000, 39, 5518-5526. [CrossRef]

33. Ambudkar, S.V.; Kim, I.W.; Sauna, Z.E. The power of the pump: Mechanisms of action of P-glycoprotein (ABCB1). Eur. J. Pharm. Sci. 2006, 27, 392-400. [CrossRef]

34. Tandon, V.R.; Kapoor, B.; Bano, G.; Gupta, S.; Gillani, Z.; Gupta, S.; Kour, D. P-glycoprotein: Pharmacological relevance. Indian J. Pharmacol. 2006, 38, 13-24. [CrossRef]

35. Rosenberg, M.F.; Kamis, A.B.; Collaghan, R.; Higgins, C.F.; Ford, R.C. Three dimensional structures of the mammalian multidrug resistance P-glycoprotein demonstrate major conformational changes in the transmembrane domains upon nucleotide binding. J. Biol. Chem. 2003, 278, 8294-8299. [CrossRef] [PubMed]

36. Loo, T.W.; Clarke, D.M. Do drug substrates enter the common drug-binding pocket of P-glycoprotein through "gates"? Biochem. Biophys. Res. Commun. 2005, 329, 419-422. [CrossRef] [PubMed]

37. Ford, J.M.; Hait, W.N. Pharmacology of drugs that alter multidrug resistance in cancer. Pharmacol. Rev. 1990, 42, 155-199. [PubMed]

38. Yang, K.; Wu, J.; Li, X. Recent advances in the research of P-glycoprotein inhibitors. Biosci. Trends 2008, 2, 137-146.

39. Lampidis, T.J.; Krishan, A.; Planas, L.; Tapiero, H. Reversal of intrinsic resistance to adriamycin in normal cells by verapamil. Cancer Drug. Deliv. 1986, 3, 251-259. [CrossRef] [PubMed] 
40. Hollt, V.; Kouba, M.; Dietel, M.; Vogt, G. Stereoisomers of calcium antagonists which differ markedly in their potencies as calcium blockers are equally effective in modulating drug transport by P-glycoprotein. Biochem. Pharmacol. 1992, 43, 2601-2608. [CrossRef]

41. Popęda, M.; Płuciennik, E.; Bednarek, A.K. Proteins in cancer multidrug resistance. Postepy Hig. Med. Dosw. 2014, 68, 616-632. [CrossRef]

42. Borowski, E.; Bontemps-Gracz, M.M.; Piwkowska, A. Strategies for overcoming ABC-transporters-mediated multidrug resistance (MDR) of tumor cells. Acta Biochim. Pol. 2005, 52, 609-627. [CrossRef]

43. Liscovitch, M.; Lavie, Y. Cancer multidrug resistance: A review of recent drug discovery research. Drugs 2002, 5, 349-355.

44. Perez-Tomas, R. Multidrug resistance: Retrospect and prospects in anti-cancer drug treatment. Curr. Med. Chem. 2006, 13, 1859-1876. [CrossRef]

45. Robey, R.W.; Massey, P.R.; Amiri-Kordestani, L.; Bates, S.E. ABC transporters: Unvalidated therapeutic targets in cancer and the CNS. Anticancer Agents Med. Chem. 2010, 10, 625-633. [CrossRef] [PubMed]

46. Zhou, S.; Lim, L.Y.; Chowbay, B. Herbal modulation of P-glycoprotein. Drug Metab. Rev. 2004, 36, 57-104. [CrossRef]

47. Zhou, S.F.; Zhou, Z.W.; Li, C.G.; Chen, X.; Yu, X.; Xue, C.C.; Herington, A. Identification of drugs that interact with herbs in drug development. Drug Discov. Today 2007, 12, 664-673. [CrossRef] [PubMed]

48. Zhang, L.; Li, Y.; Wang, Q.; Chen, Z.; Li, X.; Wu, Z.; Hu, C.; Liao, D.; Zhang, W.; Chen, Z.S. The PI3K subunits, P110 $\alpha$ and P110 $\beta$ are potential targets for overcoming P-gp and BCRP-mediated MDR in cancer. Mol. Cancer 2020, 19, 10. [CrossRef]

49. Zhang, S.; Yang, X.; Morris, M.E. Flavonoids Are Inhibitors of Breast Cancer Resistance Protein (ABCG2)-Mediated Transport. Mol. Pharmacol. 2004, 65, 1208-1216. [CrossRef]

50. Ghadia, R.; Dand, N. BCS class IV drugs: Highly notorious candidates forformulation development. J. Control. Release 2017, 248, 71-95. [CrossRef]

51. Sauna, Z.E.; Smith, M.M.; Muller, M.; Kerr, K.M.; Ambudkar, S.V. The mechanism of action of multidrug-resistance-linked P-glycoprotein. J. Bioenerg. Biomembr. 2001, 33, 481-491. [CrossRef]

52. Regev, R.; Assaraf, Y.G.; Eytan, G.D. Membrane fluidization by ether, other anesthetics, and certain agents abolishes P-glycoprotein ATPase activity and modulates efflux from multidrug-resistant cells. Eur. J. Biochem. 1999, 259, 18-24. [CrossRef]

53. Sachs-Barrable, K.; Thamboo, A.; Lee, S.D.; Wasan, K.M. Lipid excipients Peceol and Gelucire 44/14 decrease P-glycoprotein mediated efflux of rhodamine 123 partially due to modifying P-glycoprotein protein expression within Caco-2 cells. J. Pharm. Pharm. Sci. 2007, 10, 319-331. [PubMed]

54. Drori, S.; Eytan, G.D.; Assaraf, Y.G. Potentiation of anticancer-drug cytotoxicity by multidrug-resistance chemosensitizers involves alterations in membrane fluidity leading to increased membrane permeability. Eur. J. Biochem. 1995, 228, 1020-1029. [CrossRef] [PubMed]

55. Arora, A.; Byrem, T.M.; Nair, M.G.; Strasburg, G.M. Modulation of liposomal membrane fluidity by flavonoids and isoflavonoids. Arch. Biochem. Biophys. 2000, 373, 102-109. [CrossRef]

56. Boumendjel, A.; Di Pietro, A.; Dumontet, C.; Barron, D. Recent advances in the discovery of flavonoids and analogues with high affinity binding to P-glycoprotein responsible for cancer cell multidrug resistance. Med. Res. Rev. 2002, 22, 512-529. [CrossRef] [PubMed]

57. Zhang, S.; Morris, M.E. Effects of the flavonoids biochanin A, morin, phloretin, and silymarin on P-glycoprotein-mediated transport. J. Pharmacol. Exp. Ther. 2003, 304, 1258-1267. [CrossRef]

58. Conseil, G.; Baubichon-Cortay, H.; Dayan, G.; Jault, J.M.; Barron, D.; Di Pietro, A. Flavonoids: A class of modulators with bifunctional interactions at vicinal ATP- and steroid-binding sites on mouse P-glycoprotein. Proc. Natl. Acad. Sci. USA 1998, 95, 9831-9836. [CrossRef] [PubMed]

59. Boumendjel, A.; Beney, C.; Deka, N.; Mariotte, A.M.; Lawson, M.A.; Trompier, D.; Baubichon-Cortay, H.; Di Pietro, A. 4-Hydroxy6-methoxyaurones with high-affinity binding to cytosolic domain of P-glycoprotein. Chem. Pharm. Bull. 2002, 50, 854-856. [CrossRef]

60. Critchfield, J.W.; Welsh, C.J.; Phang, J.M.; Yeh, G.C. Modulation of adriamycin accumulation and efflux by flavonoids in HCT-15 colon cells: Activation of P-glycoprotein as a putative mechanism. Biochem. Pharmacol. 1994, 48, 1437-1445. [CrossRef]

61. Phang, J.M.; Poore, C.M.; Lopaczynska, J.; Yeh, G.C. Flavonol stimulated efflux of 7,12-dimethylbenz(a)-anthracene in multidrugresistant breast cancer cells. Cancer Res. 1993, 53, 5977-5981. [PubMed]

62. Scambia, G.; Ranelletti, F.O.; Panici, P.B.; De Vincenzo, R.; Bonanno, G.; Ferrandina, G.; Piantelli, M.; Bussa, S.; Rumi, C.; Cianfriglia, M.; et al. Quercetin potentiates the effect of adriamycin in a multidrug-resistant MCF-7 human breast-cancer cell line: P-glycoprotein as a possible target. Cancer Chemother. Pharmacol. 1994, 34, 459-464. [CrossRef]

63. Shapiro, A.B.; Ling, V. Effect of quercetin on Hoechst 33342 transport by purified and reconstituted P-glycoprotein. Biochem. Pharmacol. 1997, 53, 587-596. [CrossRef]

64. Choi, J.S.; Shin, S.C. Enhanced paclitaxel bioavailability after oral coadministration of paclitaxel prodrug with naringin to rats. Int. J. Pharm. 2005, 292, 149-156. [CrossRef]

65. Bukowski, K.; Kciuk, M.; Kontek, R. Mechanisms of Multidrug Resistance in Cancer Chemotherapy. Int. J. Mol. Sci. 2020, 21, 3233. [CrossRef] [PubMed]

66. Wang, J.Q.; Yang, Y.; Cai, C.Y.; Teng, Q.X.; Cui, Q.; Lin, J.; Assaraf, Y.G.; Chen, Z.S. Multidrug resistance proteins (MRPs): Structure, function and the overcoming of cancer multidrug resistance. Drug Resist. Updates 2021, 54, 100743. [CrossRef]

67. Bartel, D.P. MicroRNAs: Genomics, biogenesis, mechanism, and function. Cell 2004, 116, 281-297. [CrossRef] 
68. Bartel, D.P. MicroRNAs: Target recognition and regulatory functions. Cell 2009, 136, 215-233. [CrossRef] [PubMed]

69. Filipowicz, W.; Bhattacharyya, S.N.; Sonenberg, N. Mechanisms of post-transcriptional regulation by microRNAs: Are the answers in sight? Nat. Rev. Genet. 2008, 9, 102-114. [CrossRef] [PubMed]

70. Piriyapongsa, J.; Bootchai, C.; Ngamphiw, C.; Tongsima, S. microPIR: An integrated database of microRNA target sites within human promoter sequences. PLoS ONE 2012, 7, e33888. [CrossRef]

71. Zhao, X.; Yang, L.; Hu, J.; Ruan, J. miR-138 might reverse multidrug resistance of leukemia cells. Leuk. Res. 2010, 34, 1078-1082. [CrossRef]

72. Zhang, H.; Li, M.; Han, Y.; Zheng, X. Down-regulation of miR-27a might reverse multidrug resistance of esophageal squamous cell carcinoma. Dig. Dis. Sci. 2010, 55, 2545-2551. [CrossRef]

73. Vasudevan, S.; Tong, Y.; Steitz, J.A. Switching from repression to activation: microRNAs can up-regulate translation. Science 2007, 318, 1931-1934. [CrossRef] [PubMed]

74. Lopes-Rodrigues, V.; Seca, H.; Sousa, D.; Sousa, E.; Lima, R.T.; Vasconcelos, M.H. The network of P-glycoprotein and microRNAs interactions. Int. J. Cancer 2014, 135, 253-263. [CrossRef] [PubMed]

75. Kovalchuk, O.; Filkowski, J.; Meservy, J.; Ilnytskyy, Y.; Tryndyak, V.P.; Chekhun, V.F.; Pogribny, I.P. Involvement of microRNA-451 in resistance of the MCF-7 breast cancer cells to chemotherapeutic drug doxorubicin. Mol. Cancer Ther. 2008, 7, 2152-2159. [CrossRef] [PubMed]

76. Feng, D.D.; Zhang, H.; Zhang, P.; Zheng, Y.S.; Zhang, X.J.; Han, B.W.; Luo, X.Q.; Xu, L.; Zhou, H.; Qu, L.H.; et al. Down-regulated miR-331-5p and miR-27a are associated with chemotherapy resistance and relapse in leukaemia. J. Cell Mol. Med. 2011, 15, 2164-2175. [CrossRef] [PubMed]

77. Bao, L.; Hazari, S.; Mehra, S.; Kaushal, D.; Moroz, K.; Dash, S. Increased expression of P-glycoprotein and doxorubicin chemoresistance of metastatic breast cancer is regulated by miR-298. Am. J. Pathol. 2012, 180, 2490-2503. [CrossRef]

78. Ikemura, K.; Yamamoto, M.; Miyazaki, S.; Mizutani, H.; Iwamoto, T.; Okuda, M. MicroRNA-145 post-transcriptionally regulates the expression and function of P-glycoprotein in intestinal epithelial cells. Mol. Pharmacol. 2013, 83, 399-405. [CrossRef] [PubMed]

79. Li, Z.; Hu, S.; Wang, J.; Cai, J.; Xiao, L.; Yu, L.; Wang, Z. MiR-27a modulates MDR1/P-glycoprotein expression by targeting HIPK2 in human ovarian cancer cells. Gynecol. Oncol. 2010, 119, 125-130. [CrossRef]

80. Shang, Y.; Feng, B.; Zhou, L.; Ren, G.; Zhang, Z.; Fan, X.; Sun, Y.; Luo, G.; Liang, J.; Wu, K.; et al. The miR27b-CCNG1-P53-miR508-5p axis regulates multidrug resistance of gastric cancer. Oncotarget 2016, 7, 538-549. [CrossRef]

81. Bourguignon, L.Y.; Spevak, C.C.; Wong, G.; Xia, W.; Gilad, E. Hyaluronan-CD44 interaction with protein kinase C(epsilon) promotes oncogenic signaling by the stem cell marker Nanog and the Production of microRNA-21, leading to down-regulation of the tumor suppressor protein PDCD4, anti-apoptosis, and chemotherapy resistance in breast tumor cells. J. Biol. Chem. 2009, 284, 26533-26546. [PubMed]

82. Haenisch, S.; Werk, A.N.; Cascorbi, I. MicroRNAs and their relevance to ABC transporters. Br. J. Clin. Pharmacol. 2014, 77, 587-596. [CrossRef] [PubMed]

83. Zhao, X.; Yang, L.; Hu, J. Down-regulation of miR-27a might inhibit proliferation and drug resistance of gastric cancer cells. J. Exp. Clin. Cancer Res. 2011, 30, 55. [CrossRef]

84. Li, S.; Yang, J.; Wang, J.; Gao, W.; Ding, Y.; Ding, Y.; Jia, Z. Down-regulation of miR-210-3p encourages chemotherapy resistance of renal cell carcinoma via modulating ABCC1. Cell Biosci. 2018, 8, 9. [CrossRef] [PubMed]

85. Pan, Y.Z.; Morris, M.E.; Yu, A.M. MicroRNA-328 negatively regulates the expression of breast cancer resistance protein (BCRP/ABCG2) in human cancer cells. Mol. Pharmacol. 2009, 75, 1374-1379. [CrossRef]

86. Liu, S.; Tetzlaff, M.T.; Cui, R.; Xu, X. miR-200c inhibits melanoma progression and drug resistance through down-regulation of BMI-1. Am. J. Pathol. 2012, 181, 1823-1835. [CrossRef] [PubMed]

87. Tryndyak, V.P.; Beland, F.A.; Pogribny, I.P. E-cadherin transcriptional down-regulation by epigenetic and microRNA-200 family alterations is related to mesenchymal and drug-resistant phenotypes in human breast cancer cells. Int. J. Cancer 2010, 126, 2575-2583. [CrossRef]

88. Medarova, Z.; Pantazopoulos, P.; Yoo, B. creening of potential miRNA therapeutics for the prevention of multi-drug resistance in cancer cells. Sci. Rep. 2020, 10, 1970. [CrossRef]

89. Prevarskaya, N.; Skryma, R.; Shuba, Y. Ion Channels in Cancer: Are Cancer Hallmarks Oncochannelopathies? Physiol. Rev. 2018, 98, 559-621. [CrossRef]

90. Fan, J.J.; Huang, X. Ion Channels in Cancer: Orchestrators of Electrical Signaling and Cellular Crosstalk. Rev. Physiol. Biochem. Pharmacol. 2020. [CrossRef]

91. Capatina, A.L.; Lagos, D.; Brackenbury, W.J. Targeting Ion Channels for Cancer Treatment: Current Progress and Future Challenges. Rev. Physiol. Biochem. Pharmacol. 2020. [CrossRef]

92. Rodríguez-Rasgado, J.A.; Acuña-Macías, I.; Camacho, J. Eag1 channels as potential cancer biomarkers. Sensors 2012, 12, 5986-5995. [CrossRef] [PubMed]

93. Barlaz Us, S.; Sogut, F.; Yildirim, M.; Yetkin, D.; Yalin, S.; Yilmaz, S.N.; Comelekoglu, U. Effect of Imipramine on radiosensitivity of Prostate Cancer: An In Vitro Study. Cancer Investig. 2019, 37, 489-500. [CrossRef]

94. Teschemacher, A.G.; Seward, E.P.; Hancox, J.C.; Witchel, H.J. Inhibition of the current of heterologously expressed HERG potassium channels by imipramine and amitriptyline. Br. J. Pharmacol. 1999, 128, 479-485. [CrossRef] [PubMed] 
95. García-Ferreiro, R.E.; Kerschensteiner, D.; Major, F.; Monje, F.; Stühmer, W.; Pardo, L.A. Mechanism of block of hEag1 K+ channels by imipramine and astemizole. J. Gen. Physiol. 2004, 124, 301-317. [CrossRef]

96. Rajamanickam, S.; Panneerdoss, S.; Gorthi, A.; Timilsina, S.; Onyeagucha, B.; Kovalskyy, D.; Ivanov, D.; Hanes, M.A.; Vadlamudi, R.K.; Chen, Y.; et al. Inhibition of FoxM1-Mediated DNA Repair by Imipramine Blue Suppresses Breast Cancer Growth and Metastasis. Clin. Cancer Res. 2016, 22, 3524-3536. [CrossRef] [PubMed]

97. Charles, E.; Hammadi, M.; Kischel, P.; Delcroix, V.; Demaurex, N.; Castelbou, C.; Vacher, A.M.; Devin, A.; Ducret, T.; Nunes, P.; et al. The antidepressant fluoxetine induces necrosis by energy depletion and mitochondrial calcium overload. Oncotarget 2017, 8, 3181-3196. [CrossRef]

98. Stepulak, A.; Rzeski, W.; Sifringer, M.; Brocke, K.; Gratopp, A.; Kupisz, K.; Turski, L.; Ikonomidou, C. Fluoxetine inhibits the extracellular signal regulated kinase pathway and suppresses growth of cancer cells. Cancer Biol. Ther. 2008, 7, 1685-1693. [CrossRef]

99. Grygier, B.; Arteta, B.; Kubera, M.; Basta-Kaim, A.; Budziszewska, B.; Leśkiewicz, M.; Curzytek, K.; Duda, W.; Lasoń, W.; Maes, M. Inhibitory effect of antidepressants on B16F10 melanoma tumor growth. Pharmacol. Rep. 2013, 65, 672-681. [CrossRef]

100. Po, W.W.; Thein, W.; Khin, P.P.; Khing, T.M.; Han, K.; Park, C.H.; Sohn, U.D. Fluoxetine Simultaneously Induces Both Apoptosis and Autophagy in Human Gastric Adenocarcinoma Cells. Biomol. Ther. 2020, 28, 202-210. [CrossRef] [PubMed]

101. Lei, B.; Xu, L.; Zhang, X.; Peng, W.; Tang, Q.; Feng, C. The proliferation effects of fluoxetine and amitriptyline on human breast cancer cells and the underlying molecular mechanisms. Environ. Toxicol. Pharmacol. 2021, 83, 103586. [CrossRef] [PubMed]

102. Zhang, S.; Zhou, Z.; Gong, Q.; Makielski, J.C.; January, C.T. Mechanism of block and identification of the verapamil binding domain to HERG potassium channels. Circ. Res. 1999, 84, 989-998. [CrossRef] [PubMed]

103. Duan, J.J.; Ma, J.H.; Zhang, P.H.; Wang, X.P.; Zou, A.R.; Tu, D.N. Verapamil blocks HERG channel by the helix residue Y652 and F656 in the S6 transmembrane domain. Acta Pharmacol. Sin. 2007, 28, 959-967. [CrossRef]

104. Brocchieri, A.; Saporiti, A.; Moroni, M.; Porta, C.; Tua, A.; Grignani, G. Verapamil inhibits to different extents agonist-induced $\mathrm{Ca} 2+$ transients in human tumor cells and in vitro tumor cell growth. Invasion Metastasis. 1996, 16, 56-64.

105. Taylor, J.M.; Simpson, R.U. Inhibition of cancer cell growth by calcium channel antagonists in the athymic mouse. Cancer Res. 1992, 52, 2413-2418. [PubMed]

106. Li, P.; Zhong, D.; Gong, P.Y. Synergistic effect of paclitaxel and verapamil to overcome multi-drug resistance in breast cancer cells. Biochem. Biophys. Res. Commun. 2019, 516, 183-188. [CrossRef]

107. Holdhoff, M.; Ye, X.; Supko, J.G.; Nabors, L.B.; Desai, A.S.; Walbert, T.; Lesser, G.J.; Read, W.L.; Lieberman, F.S.; Lodge, M.A.; et al. Timed sequential therapy of the selective T-type calcium channel blocker mibefradil and temozolomide in patients with recurrent high-grade gliomas. Neuro Oncol. 2017, 19, 845-852. [CrossRef]

108. García-Quiroz, J.; García-Becerra, R.; Barrera, D.; Santos, N.; Avila, E.; Ordaz-Rosado, D.; Rivas-Suárez, M.; Halhali, A.; Rodríguez, P.; Gamboa-Domínguez, A.; et al. Astemizole synergizes calcitriol antiproliferative activity by inhibiting CYP24A1 and upregulating VDR: A novel approach for breast cancer therapy. PLoS ONE 2012, 7, e45063. [CrossRef]

109. García-Quiroz, J.; García-Becerra, R.; Santos-Martínez, N.; Barrera, D.; Ordaz-Rosado, D.; Avila, E.; Halhali, A.; Villanueva, O.; Ibarra-Sánchez, M.J.; Esparza-López, J.; et al. In vivo dual targeting of the oncogenic Ether-à-go-go-1 potassium channel by calcitriol and astemizole results in enhanced antineoplastic effects in breast tumors. BMC Cancer 2014, 14, 745. [CrossRef]

110. García-Quiroz, J.; García-Becerra, R.; Santos-Cuevas, C.; Ramírez-Nava, G.J.; Morales-Guadarrama, G.; Cárdenas-Ochoa, N.; Segovia-Mendoza, M.; Prado-Garcia, H.; Ordaz-Rosado, D.; Avila, E.; et al. Synergistic Antitumorigenic Activity of Calcitriol with Curcumin or Resveratrol is Mediated by Angiogenesis Inhibition in Triple Negative Breast Cancer Xenografts. Cancers 2019, 11, 1739. [CrossRef] [PubMed]

111. Izquierdo-Torres, E.; Rodríguez, G.; Meneses-Morales, I.; Zarain-Herzberg, A. ATP2A3 gene as an important player for resveratrol anticancer activity in breast cancer cells. Mol. Carcinog. 2017, 56, 1703-1711. [CrossRef] [PubMed]

112. Izquierdo-Torres, E.; Hernández-Oliveras, A.; Meneses-Morales, I.; Rodríguez, G.; Fuentes-García, G.; Zarain-Herzberg, Á. Resveratrol up-regulates ATP2A3 gene expression in breast cancer cell lines through epigenetic mechanisms. Int. J. Biochem. Cell Biol. 2019, 113, 37-47. [CrossRef]

113. Yang, B.; Zhang, M.; Gao, J.; Li, J.; Fan, L.; Xiang, G.; Wang, X.; Wang, X.; Wu, X.; Sun, Y.; et al. Small molecule RL71 targets SERCA2 at a novel site in the treatment of human colorectal cancer. Oncotarget 2015, 6, 37613-37625. [CrossRef] [PubMed]

114. Deshane, J.; Garner, C.C.; Sontheimer, H. Chlorotoxin inhibits glioma cell invasion via matrix metalloproteinase-2. J. Biol. Chem. 2003, 278, 4135-4144. [CrossRef] [PubMed]

115. Lui, V.C.; Lung, S.S.; Pu, J.K.; Hung, K.N.; Leung, G.K. Invasion of human glioma cells is regulated by multiple chloride channels including ClC-3. Anticancer Res. 2010, 30, 4515-4524. [PubMed]

116. Mamelak, A.N.; Jacoby, D.B. Targeted delivery of antitumoral therapy to glioma and other malignancies with synthetic chlorotoxin (TM-601). Expert Opin. Drug Deliv. 2007, 4, 175-186. [CrossRef]

117. Tamborini, M.; Locatelli, E.; Rasile, M.; Monaco, I.; Rodighiero, S.; Corradini, I.; Franchini, M.C.; Passoni, L.; Matteoli, M. Combined Approach Employing Chlorotoxin-Nanovectors and Low Dose Radiation to Reach Infiltrating Tumor Niches in Glioblastoma. ACS Nano. 2016, 10, 2509-2520. [CrossRef]

118. Dastpeyman, M.; Giacomin, P.; Wilson, D.; Nolan, M.J.; Bansal, P.S.; Daly, N.L. A C-Terminal Fragment of Chlorotoxin Retains Bioactivity and Inhibits Cell Migration. Front. Pharmacol. 2019, 10, 250. [CrossRef] 
119. Lefranc, F.; Le Rhun, E.; Kiss, R.; Weller, M. Glioblastoma quo vadis: Will migration and invasiveness reemerge as therapeutic targets? Cancer Treat. Rev. 2018, 68, 145-154. [CrossRef]

120. Khaitan, D.; Sankpal, U.T.; Weksler, B.; Meister, E.A.; Romero, I.A.; Couraud, P.O.; Ningaraj, N.S. Role of KCNMA1 gene in breast cancer invasion and metastasis to brain. BMC Cancer 2009, 9, 258. [CrossRef]

121. Bloch, M.; Ousingsawat, J.; Simon, R.; Schraml, P.; Gasser, T.C.; Mihatsch, M.J.; Kunzelmann, K.; Bubendorf, L. KCNMA1 gene amplification promotes tumor cell proliferation in human prostate cancer. Oncogene 2007, 26, 2525-2534. [CrossRef] [PubMed]

122. Schwab, A.; Reinhardt, J.; Schneider, S.W.; Gassner, B.; Schuricht, B. K (+) channel-dependent migration of fibroblasts and human melanoma cells. Cell. Physiol. Biochem. 1999, 9, 126-132. [CrossRef] [PubMed]

123. Pedarzani, P.; D’hoedt, D.; Doorty, K.B.; Wadsworth, J.D.; Joseph, J.S.; Jeyaseelan, K.; Kini, R.M.; Gadre, S.V.; Sapatnekar, S.M.; Stocker, M.; et al. a venom peptide from the Indian red scorpion (Mesobuthus tamulus) that targets small conductance Ca2+activated $\mathrm{K}+$ channels and afterhyperpolarization currents in central neurons. J. Biol. Chem. 2002, 277, 46101-46109. [CrossRef]

124. Ramírez-Cordero, B.; Toledano, Y.; Cano-Sánchez, P.; Hernández-López, R.; Flores-Solis, D.; Saucedo-Yáñez, A.L.; Chávez-Uribe, I.; Brieba, L.G.; del Río-Portilla, F. Cytotoxicity of recombinant tamapin and related toxin-like peptides on model cell lines. Chem. Res. Toxicol. 2014, 27, 960-967. [CrossRef]

125. Mayorga-Flores, M.; Chantôme, A.; Melchor-Meneses, C.M.; Domingo, I.; Titaux-Delgado, G.A.; Galindo-Murillo, R.; Vandier, C.; Del Río-Portilla, F. Novel Blocker of Onco SK3 Channels Derived from Scorpion Toxin Tamapin and Active against Migration of Cancer Cells. ACS Med. Chem. Lett. 2020, 11, 1627-1633. [CrossRef] [PubMed]

126. Duranti, C.; Arcangeli, A. Ion Channel Targeting with Antibodies and Antibody Fragments for Cancer Diagnosis. Antibodies 2019, 8, 33. [CrossRef] [PubMed]

127. Gilbert, S.M.; Gidley Baird, A.; Glazer, S.; Barden, J.A.; Glazer, A.; Teh, L.C.; King, J. A phase I clinical trial demonstrates that nfP2 $\times 7$-targeted antibodies provide a novel, safe and tolerable topical therapy for basal cell carcinoma. Br. J. Dermatol. 2017, 177, 117-124. [CrossRef] [PubMed]

128. Gilbert, S.M.; Oliphant, C.J.; Hassan, S.; Peille, A.L.; Bronsert, P.; Falzoni, S.; Di Virgilio, F.; McNulty, S.; Lara, R. ATP in the tumour microenvironment drives expression of nfP2X7, a key mediator of cancer cell survival. Oncogene 2019, 38, 194-208. [CrossRef]

129. Hirschler-Laszkiewicz, I.; Chen, S.J.; Bao, L.; Wang, J.; Zhang, X.Q.; Shanmughapriya, S.; Keefer, K.; Madesh, M.; Cheung, J.Y.; Miller, B.A. The human ion channel TRPM2 modulates neuroblastoma cell survival and mitochondrial function through Pyk2, CREB, and MCU activation. Am. J. Physiol. Cell Physiol. 2018, 315, C571-C586. [CrossRef]

130. Chen, S.J.; Bao, L.; Keefer, K.; Shanmughapriya, S.; Chen, L.; Lee, J.; Wang, J.; Zhang, X.Q.; Hirschler-Laszkiewicz, I.; Merali, S.; et al. Transient receptor potential ion channel TRPM2 promotes AML proliferation and survival through modulation of mitochondrial function, ROS, and autophagy. Cell Death Dis. 2020, 11, 247. [CrossRef]

131. Almasi, S.; Kennedy, B.E.; El-Aghil, M.; Sterea, A.M.; Gujar, S.; Partida-Sánchez, S.; El Hiani, Y. TRPM2 channel-mediated regulation of autophagy maintains mitochondrial function and promotes gastric cancer cell survival via the JNK-signaling pathway. J. Biol. Chem. 2018, 293, 3637-3650. [CrossRef]

132. Almasi, S.; Long, C.Y.; Sterea, A.; Clements, D.R.; Gujar, S.; El Hiani, Y. TRPM2 Silencing Causes G2/M Arrest and Apoptosis in Lung Cancer Cells via Increasing Intracellular ROS and RNS Levels and Activating the JNK Pathway. Cell. Physiol. Biochem. 2019, 52, 742-757. [PubMed]

133. Sales, T.T.; Resende, F.F.; Chaves, N.L.; Titze-De-Almeida, S.S.; Báo, S.N.; Brettas, M.L.; Titze-De-Almeida, R. Suppression of the Eag1 potassium channel sensitizes glioblastoma cells to injury caused by temozolomide. Oncol. Lett. 2016, 12, 2581-2589. [CrossRef]

134. Kondratska, K.; Kondratskyi, A.; Yassine, M.; Lemonnier, L.; Lepage, G.; Morabito, A.; Skryma, R.; Prevarskaya, N. Orai1 and STIM1 mediate SOCE and contribute to apoptotic resistance of pancreatic adenocarcinoma. Biochim. Biophys. Acta 2014, 1843, 2263-2269. [CrossRef]

135. Bai, Y.; Liao, H.; Liu, T.; Zeng, X.; Xiao, F.; Luo, L.; Guo, H.; Guo, L. MiR-296-3p regulates cell growth and multi-drug resistance of human glioblastoma by targeting ether-à-go-go (EAG1). Eur. J. Cancer 2013, 49, 710-724. [CrossRef]

136. Shi, X.; He, W.; Guo, S.; Zhang, B.; Ren, S.; Liu, K.; Sun, T.; Cui, J. RNA-seq Analysis of the SCN1A-KO Model based on CRISPR/Cas9 Genome Editing Technology. Neuroscience 2019, 398, 1-11. [CrossRef]

137. Chai, S.; Kan, S.; Sun, R.; Zhou, R.; Sun, Y.; Chen, W.; Yu, B. Fabricating polydopamine-coated MoSe2-wrapped hollow mesoporous silica nanoplatform for controlled drug release and chemo-photothermal therapy. Int. J. Nanomed. 2018, 13, 7607-7621. [CrossRef]

138. Kulbacka, J.; Chodaczek, G.; Rossowska, J.; Szewczyk, A.; Saczko, J.; Bazylińska, U. Investigating the photodynamic efficacy of chlorin e6 by millisecond pulses in metastatic melanoma cells. Bioelectrochemistry 2020, 138, 107728. [CrossRef] [PubMed]

139. Buckner, C.A.; Buckner, A.L.; Koren, S.A.; Persinger, M.A.; Lafrenie, R.M. Inhibition of cancer cell growth by exposure to a specific time-varying electromagnetic field involves T-type calcium channels. PLoS ONE 2015, 10, e0124136. [CrossRef] [PubMed]

140. Wust, P.; Kortüm, B.; Strauss, U.; Nadobny, J.; Zschaeck, S.; Beck, M.; Stein, U.; Ghadjar, P. Non-thermal effects of radiofrequency electromagnetic fields. Sci. Rep. 2020, 10, 13488. [CrossRef]

141. Heldin, C.H.; Lu, B.; Evans, R.; Gutkind, J.S. Signals and Receptors. Cold Spring Harb. Perspect. Biol. 2016, 8, a005900. [CrossRef]

142. Traynelis, S.F.; Wollmuth, L.P.; McBain, C.J.; Menniti, F.S.; Vance, K.M.; Ogden, K.K.; Hansen, K.B.; Yuan, H.; Myers, S.J.; Dingledine, R. Glutamate receptor ion channels: Structure, regulation, and function. Pharmacol. Rev. 2010, 62, 405-496. [CrossRef] [PubMed] 
143. Bar-Shavit, R.; Maoz, M.; Kancharla, A.; Nag, J.K.; Agranovich, D.; Grisaru-Granovsky, S.; Uziely, B. G Protein-Coupled Receptors in Cancer. Int. J. Mol. Sci. 2016, 17, 1320. [CrossRef] [PubMed]

144. Gocek, E.; Moulas, A.N.; Studzinski, G.P. Non-receptor protein tyrosine kinases signaling pathways in normal and cancer cells. Crit. Rev. Clin. Lab. Sci. 2014, 51, 125-137. [CrossRef]

145. Guicciardi, M.E.; Gores, G.J. Life and death by death receptors. FASEB J. 2009, 23, 625-1637. [CrossRef]

146. Lemmon, M.A.; Schlessinger, J. Cell signaling by receptor-tyrosine kinases. Cell 2010, 25, 1117-1134. [CrossRef]

147. Fu, Q.; Shi, Q.; West, T.M.; Xiang, Y.K. Cross-Talk Between Insulin Signaling and G Protein-Coupled Receptors. J. Cardiovasc. Pharmacol. 2017, 70, 74-86. [CrossRef]

148. Bagur, R.; Hajnóczky, G. Intracellular Ca2+ sensing: Role in calcium homeostasis and signaling. Mol. Cell 2017, 66, 780-788. [CrossRef] [PubMed]

149. Barnes, P.J. Receptor heterodimerization: A new level of cross-talk. J. Clin. Investig. 2006, 116, 1210-1212. [CrossRef] [PubMed]

150. Lorenz, U. SHP-1 and SHP-2 in T cells: Two phosphatases functioning at many levels. Immunol. Rev. 2009, 228, 342-359. [CrossRef]

151. Aittaleb, M.; Boguth, C.A.; Tesmer, J.J. Structure and function of heterotrimeric G protein-regulated Rho guanine nucleotide exchange factors. Mol. Pharmacol. 2010, 77, 111-125. [CrossRef]

152. Grusch, M.; Petz, M.; Metzner, T.; Oztürk, D.; Schneller, D.; Mikulits, W. The crosstalk of RAS with the TGF- $\beta$ family during carcinoma progression and its implications for targeted cancer therapy. Curr. Cancer Drug. Targets 2010, 10, 849-857. [CrossRef]

153. Mendelson, K.; Swendeman, S.; Saftig, P.; Blobel, C.P. Stimulation of platelet-derived growth factor receptor beta (PDGFRbeta) activates ADAM17 and promotes metalloproteinase-dependent cross-talk between the PDGFRbeta and epidermal growth factor receptor (EGFR) signaling pathways. J. Biol. Chem. 2010, 285, 25024-25032. [CrossRef]

154. Desai, A.J.; Miller, L.L. Changes in the plasma membrane in metabolic disease: Impact of the membrane environment on G protein-coupled receptor structure and function. Br. J. Pharmacol. 2018, 175, 4009-4025. [CrossRef] [PubMed]

155. Fabbro, D.; Cowan-Jacob, S.W.; Möbitz, H.; Martiny-Baron, G. Targeting cancer with small-molecular-weight kinase inhibitors. Methods Mol. Biol. 2012, 795, 1-34. [PubMed]

156. Xie, Y.H.; Chen, Y.H.; Fang, J.Y. Comprehensive review of targeted therapy for colorectal cancer. Signal Transduct. Target. Ther. 2020, 5, 22. [PubMed]

157. Du, Z.; Lovely, C.M. Mechanisms of receptor tyrosine kinase activation in cancer. Mol. Cancer 2018, 17, 58. [CrossRef] [PubMed]

158. Drescher, D.; Moehler, M.; Gockel, I.; Frerichs, K.; Müller, A.; Dünschede, F.; Borschitz, T.; Biesterfeld, S.; Holtmann, M.; Wehler, T.; et al. Coexpression of receptor-tyrosine-kinases in gastric adenocarcinoma-a rationale for a molecular targeting strategy? World J. Gastroenterol. 2007, 26, 3605-3609. [CrossRef]

159. Pottier, C.; Fresnais, M.; Gilon, M.; Jérusalem, G.; Longuespée, R.; Sounni, N.E. Tyrosine Kinase Inhibitors in Cancer: Breakthrough and Challenges of Targeted Therapy. Cancers 2020, 12, 731. [CrossRef]

160. Yamaoka, T.; Kusumoto, S.; Ando, K.; Ohba, M.; Ohmori, T. Receptor Tyrosine Kinase-Targeted Cancer therapy International. Int. J. Mol. Sci. 2018, 19, 3491. [CrossRef] [PubMed]

161. Lasota, J.; Miettinen, M. KIT and PDGFRA mutations in gastrointestinal stromal tumors (GISTs). Semin. Diagn. Pathol. 2006, 23, 91-102. [CrossRef] [PubMed]

162. Toffalini, F.; Kallin, A.; Vandenberghe, P.; Pierre, P.; Michaux, L.; Cools, J.; Demoulin, J.B. The fusion proteins TEL-PDGFRbeta and FIP1L1-PDGFRalpha escape ubiquitination and degradation. Haematologica 2009, 94, 1085-1093. [CrossRef] [PubMed]

163. Ross, J.S.; Slodkowska, E.A.; Symmans, W.F.; Pusztai, L.; Ravdin, P.M.; Hortobagyi, G.N. The HER-2 receptor and breast cancer: Ten years of targeted anti-HER-2 therapy and personalized medicine. Oncologist 2009, 14, 320-368. [CrossRef]

164. Shawver, L.K.; Slamon, D.; Ullrich, A. Smart drugs: Tyrosine kinase inhibitors in cancer therapy. Cancer Cell 2002, 1, 117-123. [CrossRef]

165. Gibson, T.B.; Ranganathan, A.; Grothey, A. Randomized phase III trial results of panitumumab, a fully human anti-epidermal growth factor receptor monoclonal antibody, in metastatic colorectal cancer. Clin. Colorectal Cancer 2006, 6, 29-31. [CrossRef]

166. Vermorken, J.B.; Mesia, R.; Rivera, F.; Remenar, E.; Kawecki, A.; Rottey, S.; Erfan, J.; Zabolotnyy, D.; Kienzer, H.R.; Cupissol, D.; et al. Platinum-based chemotherapy plus cetuximab in head and neck cancer. N. Engl. J. Med. 2008, 359, 1116-1127. [CrossRef]

167. Romond, E.H.; Perez, E.A.; Bryant, J.; Suman, V.J.; Geyer, C.E.J.; Davidson, N.E.; Tan-Chiu, E.; Martino, S.; Paik, S.; Kaufman, P.A.; et al. Trastuzumab plus adjuvant chemotherapy for operable HER2-positive breast cancer. N. Engl. J. Med. 2005, 353, $1673-1684$. [CrossRef]

168. von Minckwitz, G.; Procter, M.; de Azambuja, E.; Zardavas, D.; Benyunes, M.; Viale, G.; Suter, T.; Arahmani, A.; Rouchet, N.; Clark, E.; et al. APHINITY Steering Committee and Investigators. Adjuvant Pertuzumab and Trastuzumab in early HER2-positive breast cancer. N. Engl. J. Med. 2017, 377, 122-131. [CrossRef] [PubMed]

169. Lengyel, E.; Prechtel, D.; Resau, J.H.; Gauger, K.; Welk, A.; Lindemann, K.; Salanti, G.; Richter, T.; Knudsen, B.; Vande Woude, G.F.; et al. C-met overexpression in node-positive breast cancer identifies patients with poor clinical outcome independent of her2/neu. Int. J. Cancer 2005, 113, 678-682. [CrossRef]

170. Vigh, L.; Escribá, P.V.; Sonnleitner, A.; Sonnleitner, M.; Piotto, S.; Maresca, B.; Horváth, I.; Harwood, J.L. The significance of lipid composition for membrane activity: New concepts and ways of assessing function. Prog. Lipid Res. 2005, 44, 303-344. [CrossRef]

171. Frewein, M.; Kollmitzer, B.; Heftberger, P.; Pabst, G. Lateral pressure-mediated protein partitioning into liquid-ordered/liquiddisordered domains. Soft Matter. 2016, 12, 3189-3195. [CrossRef] 
172. Ghysels, A.; Krämer, A.; Venable, R.M.; Teague, W.E., Jr.; Lyman, E.; Gawrisch, K.; Pastor, R.W. Permeability of membranes in the liquid ordered and liquid disordered phases. Nat. Commun. 2019, 10, 5616. [CrossRef] [PubMed]

173. Simons, K.; Ikonen, E. Functional rafts in cell membranes. Nature 1997, 387, 569-572. [CrossRef]

174. Alves, A.C.; Ribeiro, D.; Nunes, C.; Reis, S. Biophysics in cancer: The relevance of drug-membrane interaction studies. Biochim. Biophys. Acta 2016, 1858, 2231-2244. [CrossRef] [PubMed]

175. Adada, M.; Luberto, C.; Canals, D. Inhibitors of the sphingomyelin cycle: Sphingomyelin synthases and sphingomyelinases. Chem. Phys. Lipids 2016, 197, 45-59. [CrossRef]

176. Alves, A.C.; Ribeiro, D.; Horta, M.; Lima, J.; Nunes, C.; Reis, S. A biophysical approach to daunorubicin interaction with model membranes: Relevance for the drug's biological activity. J. R. Soc. Interface 2017, 14, 20170408. [CrossRef] [PubMed]

177. Barceló-Coblijn, G.; Martin, M.L.; de Almeida, R.F.; Noguera-Salvà, M.A.; Marcil-la-Etxenike, A.; Guardiola-Serrano, F.; Lüth, A.; Kleuser, B.; Halver, J.E.; Escribá, P.V. Sphingomyelin and sphingomyelin synthase (SMS) in the malignant transformation of glioma cells and in 2-hydroxyoleic acid therapy. Proc. Natl. Acad. Sci. USA 2011, 6, 19569-19574. [CrossRef] [PubMed]

178. Casares, D.; Escribá, P.V.; Rosselló, C.A. Membrane Lipid Composition: Effect on Membrane and Organelle Structure, Function and Compartmentalization and Therapeutic Avenues. Int. J. Mol. Sci. 2019, 20, 2167. [CrossRef]

179. Hao, M.; Mukherjee, S.; Sun, Y.; Maxfield, F.R. Effects of cholesterol depletion and increased lipid unsaturation on the properties of endocytic membranes. J. Biol. Chem. 2004, 279, 14171-14178. [CrossRef]

180. Siddiqui, R.A.; Zerouga, M.; Wu, M.; Castillo, A.; Harvey, K.; Zaloga, G.P.; Stillwell, W. Anticancer properties of propofoldocosahexaenoate and propofol-eicosapentaenoate on breast cancer cells. Breast Cancer Res. 2005, 7, R645. [CrossRef]

181. Lajoie, P.; Nabi, I.R. Lipid rafts, caveolae, and their endocytosis. Int. Rev. Cell Mol. Biol. 2010, 282, $135-163$.

182. Huang, Q.; Shen, H.-M.; Shui, G.; Wenk, M.R.; Ong, C.-N. Emodin inhibits tumor cell adhesion through disruption of the membrane lipid raft-associated integrin signaling pathway. Cancer Res. 2006, 66, 5807-5815. [CrossRef] [PubMed]

183. Head, B.P.; Patel, H.H.; Insel, P.A. Interaction of membrane/lipid rafts with the cytoskeleton: Impact on signaling and function: Membrane/lipid rafts, mediators of cytoskeletal arrangement and cell signaling. Biochim. Biophys. Acta 2014, 1838, 532-545. [CrossRef] [PubMed]

184. Escribá, P.V.; Busquets, X.; Inokuchi, J.-I.; Balogh, G.; Török, Z.; Horváth, I.; Harwood, J.L.; Vígh, L. Membrane lipid therapy: Modulation of the cell membrane composition and structure as a molecular base for drug discovery and new disease treatment. Prog. Lipid Res. 2015, 59, 38-53. [CrossRef] [PubMed]

185. van der Luit, A.H.; Budde, M.; Ruurs, P.; Verheij, M.; van Blitterswijk, W.J. Alkyl-lysophospholipid accumulates in lipid rafts and induces apoptosis via raft-dependent endocytosis and inhibition of phosphatidylcholine synthesis. J. Biol. Chem. 2002, 18, 39541-39547. [CrossRef] [PubMed]

186. Walczewska, A.; Dziedzic, B.; Stulczewski, D.; Zgórzyńska, E. Cell membranes. Molecular lipid therapy. Postepy Hig. Med. Dosw 2017, 71, 1239-1250. [CrossRef]

187. Delmas, D.; Aires, V.; Colin, D.J.; Limagne, E.; Scagliarini, A.; Cotte, A.K.; Ghiringhelli, F. Importance of lipid microdomains, rafts, in absorption, delivery, and biological effects of resveratrol. Ann. N. Y. Acad. Sci. 2013, 1290, 90-97. [CrossRef] [PubMed]

188. Böckmann, R.A.; De Groot, B.L.; Kakorin, S.; Neumann, E.; Grubmüller, H. Kinetics, statistics, and energetics of lipid membrane electroporation studied by molecular dynamics simulations. Biophys. J. 2008, 95, 1837-1850. [CrossRef] [PubMed]

189. Kotnik, T.; Rems, L.; Tarek, M.; Miklavcic, D. Membrane Electroporation and Electropermeabilization: Mechanisms and Models Annu. Rev. Biophys. 2019, 48, 63-91. [CrossRef] [PubMed]

190. Gowrishankar, T.R.; Esser, A.T.; Vasilkoski, Z.; Smith, K.C.; Weaver, J.C. Microdosimetry for conventional and supraelectroporation in cells with organelles. Biochem. Biophys. Res. Commun. 2006, 341, 1266-1276. [CrossRef] [PubMed]

191. Saulis, G.; Saulè, R. Size of the pores created by an electric pulse: Microsecond vs. millisecond pulses. Biochim. Biophys. Acta 2012, 1818, 3032-3039. [CrossRef] [PubMed]

192. Tieleman, D.P. The molecular basis of electroporation. BMC Biochem. 2004, 5, 1-12. [CrossRef] [PubMed]

193. Benov, L.C.; Antonov, P.A.; Ribarov, S.R. Oxidative damage of the membrane lipids after electroporation. Gen. Physiol. Biophys. 1994, 13, 85-97. [PubMed]

194. Gabriel, B.; Teissié, J. Generation of reactive-oxygen species induced by electropermeabilization of Chinese hamster ovary cells and their consequence on cell viability. Eur. J. Biochem. 1994, 223, 25-33. [CrossRef] [PubMed]

195. Maccarrone, M.; Bladergroen, M.R.; Rosato, N.; Agro, A.F. Role of lipid peroxidation in electroporation-induced cell permeability. Biochem. Biophys. Res. Commun. 1995, 209, 417-425. [CrossRef]

196. Tavazzi, B.; Di, P.D.; Amorini, A.M.; Fazzina, G.; Tuttobene, M.; Giardina, B.; Lazzarino, G. Energy metabolism and lipid peroxidation of human erythrocytes as a function of increased oxidative stress. Eur. J. Biochem. 2000, 267, 684-689. [CrossRef]

197. Valko, M.; Rhodes, C.J.; Moncol, J.; Izakovic, M.; Mazur, M. Free radicals, metals and antioxidants in oxidative stress-induced cancer. Chem. Biol. Interact. 2006, 160, 1-40. [CrossRef]

198. Min, B.; Ahn, D. Mechanism of lipid peroxidation in meat and meat products-a review. Food Sci. Biotechnol. $2005,14,152-163$.

199. Fortier, C.A.; Guan, B.; Cole, R.B.; Tarr, M.A. Covalently bound fluorescent probes as reporters for hydroxyl radical penetration into liposomal membranes. Free Radic. Biol. Med. 2009, 46, 1376-1385. [CrossRef]

200. Kohen, R.; Nyska, A. Oxidation of biological systems: Oxidative stress phenomena, antioxidants, redox reactions, and methods for their quantification. Toxicol. Pathol. 2002, 30, 620-650. [CrossRef] 
201. Bailey, M.S.; Lander, A.; Darley-Usmar, V. Mitochondrial proteomics in free radical research. Free Rad. Biol. Med. 2005, 38, 531-549. [CrossRef] [PubMed]

202. Vernier, P.T.; Sun, Y.H.; Gundersen, M.A. Nanoelectropulse-driven membrane perturbation and small molecule permeabilization. BMC Cell Biol. 2006, 7, 37. [CrossRef] [PubMed]

203. Pakhomov, A.G.; Kolb, J.F.; White, J.A.; Joshi, R.P.; Xiao, S.; Schoenbach, K.H. Long-lasting plasma membrane permeabilization in mammalian cells by nanosecond pulsed electric field (nsPEF). Bioelectromagnetics 2007, 28, 655-663. [CrossRef]

204. Hojman, P.; Gissel, H.; Andre, F.M.; Cournil-Henrionnet, C.; Eriksen, J.; Gehl, J.; Mir, L.M. Physiological effects of high and low voltage pulse combinations for gene electrotransfer in muscle. Hum. Gene Ther. 2008, 19, 1249-1260. [CrossRef]

205. Vernier, P.T.; Levine, Z.A.; Wu, Y.H.; Joubert, V.; Ziegler, M.J.; Mir, L.M.; Tieleman, D.P. Electroporating fields target oxidatively damaged areas in the cell membrane. PLoS ONE 2009, 11, 1-8. [CrossRef] [PubMed]

206. Bonnafous, P.; Vernhes, M.C.; Teissie, J.; Gabriel, B. The generation of reactive-oxygen species associated with long-lasting pulse-induced electropermeabilization of mammalian cells is based on a non-destructive alteration of the plasma membrane. Biochim. Biophys. Acta-Biomembr. 1999, 1461, 123-134. [CrossRef]

207. Sakharov, D.V.; Elstak, E.D.R.; Chernyak, B.; Wirtz, K.W.A. Prolonged lipid oxidation after photodynamic treatment. Study with oxidation-sensitive probe c11-bodipy581/591. FEBS Lett. 2005, 579, 1255-1260. [CrossRef]

208. Zhou, Y.; Berry, C.K.; Storer, P.A.; Raphael, R.M. Peroxidation of polyunsaturated phosphatidyl-choline lipids during electroformation. Biomaterials 2007, 28, 1298-1306. [CrossRef]

209. Shevchuk, I.N.; Chekulayev, V.A.; Checulayeva, L.V. The role of lipid peroxidation and protein degradation in the photodestruction of Ehrlich ascites carcinoma cells sensitized by hemathoporphirin derivative. Exp. Oncol. 2002, 24, $216-224$.

210. Biedinger, U.; Youngman, R.J.; Schnabl, H. Differential effects of electrofusion and electropermeabilization parameters on the membrane integrity of plant protoplasts. Planta 1990, 180, 598-602. [CrossRef]

211. Yeo, S.K.; Liong, M.T. Effect of electroporation on viability and bioconversion of isoflavones in mannitol-soymilk fermented by lactobacilli and bifidobacteria. J. Sci. Food Agric. 2013, 93, 396-409. [CrossRef]

212. Yun, O.; Zeng, X.A.; Brennan, C.S.; Han, Z. Effect of pulsed electric field on membrane lipids and oxidative injury of Salmonella typhimurium. Int. J. Mol. Sci. 2016, 17, 1374. [CrossRef]

213. Maccarrone, M.; Rosato, N.; Agro, A.F. Electroporation enhances cell membrane peroxidation and luminescence. Biochem. Biophys. Res. Commun. 1995, 206, 238-245. [CrossRef] [PubMed]

214. Boonnoy, P.; Jarerattanachat, V.; Karttunen, M.; Wong-Ekkabut, J. Bilayer deformation, pores, and micellation induced by oxidized lipids. J. Phys. Chem. Lett. 2015, 6, 4884-4888. [CrossRef] [PubMed]

215. Breton, M.; Delemotte, L.; Silve, A.; Mir, L.M.; Tarek, M. Transport of siRNA through lipid membranes driven by nanosecond electric pulses: An experimental and computational study. J. Am. Chem. Soc. 2012, 134, 13938-13941. [CrossRef]

216. Nidernhofer, L.J.; Daniels, J.S.; Rouzer, C.A.; Greene, R.E.; Marnett, L.J. Malonodialdehyde, a product of lipid peroxidation, is mutagenic in human cells. J. Biol. Chem. 2003, 278, 31426-31433. [CrossRef]

217. Pakhomova, O.N.; Khorokhorina, V.A.; Bowman, A.M.; Rodaitè-Riševičienė, R.; Saulis, G.; Xiao, S.; Pakhomov, A.G. Oxidative effects of nanosecond pulsed electric field exposure in cells and cell-free media. Arch. Biochem. Biophys 2012, 527, 55-64. [CrossRef] [PubMed]

218. Tsong, T.Y. On electroporation of cell membranes and some related phenomena. Bioelectrochem. Bioenerg. 1990, 24, 271-295. [CrossRef]

219. Tsong, T.Y. Electroporation of cell membranes. Biophys. J. 1991, 60, 297-306. [CrossRef]

220. Burke, R.C.; Bardet, S.M.; Carr, L.; Romanenko, S.; Arnaud-Cormos, D.; Leveque, P.; O'Connor, R.P. Nanosecond pulsed electric fields depolarize transmembrane potential via voltage-gated $\mathrm{K}+, \mathrm{Ca} 2+$ and TRPM8 channels in U87 glioblastoma cells. Biochim. Biophys. Acta 2017, 1859, 2040-2050. [CrossRef] [PubMed]

221. Chen, W.; Zhongsheng, Z.; Lee, R.C. Supramembrane potential-induced electroconformational changes in sodium channel proteins: A potential mechanism involved in electric injury. Burns 2006, 32, 52-59. [CrossRef]

222. Nesin, V.; Bowman, A.M.; Xiao, S.; Pakhomov, A.G. Cell permeabilization and inhibition of voltage gated $\mathrm{Ca} 2+$ and $\mathrm{Na}+\mathrm{channel}$ currents by nanosecond pulsed electric field. Bioelectromagnetics 2012, 33, 394-404. [CrossRef]

223. Nesin, V.; Pakhomov, A.G. Inhibition of voltage-gated Na+ current by nanosecond electric field (nsPEF) is not mediated by Na+ influx or Ca2+ signaling. Bioelectromagnetics 2012, 33, 443-451. [CrossRef]

224. Pakhomov, A.G.; Semenov, I.; Casciola, M.; Xiao, S. Neuronal excitation and permeabilization by 200-ns pulsed electric field: An optical membrane potential study with FluoVolt dye. Biochim. Biophys. Acta 2017, 1859, 1273-1281. [CrossRef] [PubMed]

225. Yang, L.; Craviso, G.L.; Vernier, P.T.; Chatterjee, I.; Leblanc, N. Nanosecond electric pulses differentially affect inward and outward currents in patch clamped adrenal chromaffin cells. PLoS ONE 2017, 12, e181002. [CrossRef]

226. Teissié, J.; Tsong, T.Y. Evidence of voltage-induced channel opening in Na/K ATPase of human erythrocyte membrane. J. Membr. Biol. 1980, 55, 133-1340. [CrossRef] [PubMed]

227. Svitkina, T. The Actin Cytoskeleton and Actin-Based Motility. Cold Spring Harb. Perspect. Biol. 2018, 1, a018267. [CrossRef]

228. Humphrey, J.D.; Dufresne, E.R.; Schwartz, M.A. Mechanotransduction and extracellular matrix homeostasis. Nat. Rev. Mol. Cell Biol. 2014, 15, 802-812. [CrossRef] [PubMed]

229. Thompson, G.L.; Roth, C.; Tolstykh, G.; Kuipers, M.; Ibey, B.L. Disruption of the actin cortex contributes to susceptibility of mammalian cells to nanosecond pulsed electric fields. Bioelectromagnetics 2014, 35, 262-272. [CrossRef] 
230. Stacey, M.; Fox, P.; Buescher, S.; Kolb, J. Nanosecond pulsed electric field induced cytoskeleton, nuclear membrane and telomere damage adversely impact cell survival. Bioelectrochemistry 2011, 82, 131-134. [CrossRef]

231. Pehlivanova, V.N.; Tsoneva, I.H.; Tzoneva, R.D. Multiple effects of electroporation on the adhesive behaviour of breast cancer cells and fibroblasts. Cancer Cell Int. 2012, 12, 9. [CrossRef] [PubMed]

232. Cordeiro, R.M. Reactive oxygen species at phospholipid bilayers: Distribution, mobility and permeation. Biochim. Biophys. Acta Biomembr. 2014, 1838, 438-444. [CrossRef] [PubMed]

233. Napotnik, T.B.; Reberšek, M.; Vernier, P.T.; Mali, B.; Miklavčič, D. Effects of high voltage nanosecond electric pulses on eucaryotic cells (in vitro): A systematic review. Bioelectrochemistry 2016, 110, 1-12. [CrossRef] [PubMed]

234. Steuer, A.; Wende, K.; Babica, P.; Kolb, J.B. Elasticity and tumorigenic characteristics of cells in a monolayer after nanosecond pulsed electric field exposure. Eur. Biophys. J. 2017, 46, 567-580. [CrossRef]

235. Szewczyk, A.; Gehl, J.; Daczewska, M.; Saczko, J.; Frandsen, S.K.; Kulbacka, J. Calcium electroporation for treatment of sarcoma in preclinical studies. Oncotarget 2018, 14, 11604-11618. [CrossRef]

236. Graybill, P.M.; Davalos, R.V. Cytoskeletal disruption after electroporation and its significance to pulsed electric field therapies. Cancers 2020, 12, 1132. [CrossRef] [PubMed]

237. Kollman, J.M.; Merdes, A.; Mourey, L.; Agard, D.A. Microtubule nucleation by $\gamma$-tubulin complexes. Nat. Rev. Mol. Cell Biol. 2011, 12, 709-721. [CrossRef] [PubMed]

238. Harkin, F.G.; Hay, E.D. Effects of electroporation on the tubulin cytoskeleton and directed migration of corneal fibroblasts cultured within collagen matrices. Cell Motil. Cytoskelet. 1996, 35, 345-357. [CrossRef]

239. Meulenberg, C.J.W.; Todorovic, V.; Cemazar, M. Differential Cellular Effects of Electroporation and Electrochemotherapy in Monolayers of Human Microvascular Endothelial Cells. PLoS ONE 2012, 12, e52713. [CrossRef] [PubMed]

240. Kanthou, C.; Kranjc, S.; Sersa, G.; Tozer, G.; Zupanic, A.; Cemazar, M. The endothelial cytoskeleton as a target of electroporationbased therapies. Mol. Cancer Ther. 2006, 12, 3145-3152. [CrossRef]

241. Carr, L.; Bardet, S.M.; Burke, R.C.; Arnaud-Cormos, D.; Leveque, P.; O'Connor, R.P. Calcium-independent disruption of microtubule dynamics by nanosecond pulsed electric fields in U87 human glioblastoma cells. Sci. Rep. 2017, 7, 41267. [CrossRef]

242. Sanghvi-Shah, R.; Weber, G.F. Intermediate filaments at the junction of mechanotransduction, migration, and development. Front. Cell Dev. Biol. 2017, 5, 81. [CrossRef]

243. Thompson, G.L.; Roth, C.C.; Kuipers, M.A.; Tolstykh, G.P.; Beier, H.T.; Ibey, B.L. Permeabilization of the nuclear envelope following nanosecond pulsed electric field exposure. Biochem. Biophys. Res. Commun. 2016, 470, 35-40. [CrossRef] [PubMed]

244. Yarmush, M.L.; Golberg, A.; Serša, G.; Kotnik, T.; Miklavčič, D. Electroporation-based technologies for medicine: Principles, applications, and challenges. Annu. Rev. Biomed. Eng. 2014, 16, 295-320. [CrossRef]

245. Giardino, R.; Fini, M.; Bonazzi, V.; Cadossi, R.; Nicolini, A.; Carpi, A. Electrochemotherapy a novel approach to the treatment of metastatic nodules on the skin and subcutaneous tissues. Biomed. Pharmacother. 2006, 60, 458-462. [CrossRef]

246. Lv, Y.; Zhang, Y.; Huang, J.; Wang, Y.; Rubinsky, B. Study on Nonthermal Irreversible Electroporation of the Thyroid. Technol. Cancer Res. Treat. 2019, 18, 1533033819876307. [CrossRef] [PubMed]

247. Cemazar, M.; Jarm, T.; Sersa, G. Cancer electrogene therapy with interleukin-12. Curr. Gene Ther. 2010, 10, 300-311. [CrossRef]

248. Rosati, M.; Valentin, A.; Jalah, R.; Patel, V.; von Gegerfelt, A.; Bergamaschi, C.; Alicea, C.; Weiss, D.; Treece, J.; Pal, R.; et al. Increased immune responses in rhesus macaques by DNA vaccination combined with electroporation. Vaccine 2008, 26, 5223-5229. [CrossRef]

249. Ward, M.; Wu, J. Ultrasound-induced Cell Lysis and Sonoporation Enhanced by Contrast Agents. J. Acoust. Soc. Am. 1999, 105, 2951-2957. [CrossRef] [PubMed]

250. Escoffre, J.M.; Novell, A.; Piron, J.; Zeghimi, A.; Doinikov, A.; Bouakaz, A. Microbubble Attenuation and Destruction: Are They Involved in Sonoporation Efficiency? IEEE Trans. Ultrason. Ferroelectr. Freq. Control. 2013, 60, 46-52. [CrossRef]

251. van Wamel, A.; Kooiman, K.; Harteveld, M.; Emmer, M.; ten Cate, F.J.; Versluis, M.; de Jong, N. Vibrating Microbubbles Poking Individual Cells: Drug Transfer into Cells via Sonoporation. J. Control. Release 2006, 112, 149-155. [CrossRef]

252. Yang, Y.; Li, Q.; Guo, X.; Tu, J.; Zhang, D. Mechanisms Underlying Sonoporation: Interaction between Microbubbles and Cells. Ultrason. Sonochem. 2020, 67, 105096. [CrossRef]

253. Lentacker, I.; De Cock, I.; Deckers, R.; De Smedt, S.C.; Moonen, C.T.W. Understanding Ultrasound Induced Sonoporation: Definitions and Underlying Mechanisms. Adv. Drug Deliv. Rev. 2014, 72, 49-64. [CrossRef] [PubMed]

254. Kooiman, K.; Vos, H.J.; Versluis, M.; De Jong, N. Acoustic Behavior of Microbubbles and Implications for Drug Delivery. Adv. Drug Deliv. Rev. 2014, 72, 28-48. [CrossRef] [PubMed]

255. Bouakaz, A.; Versluis, M.; De Jong, N. High-Speed Optical Observations of Contrast Agent Destruction. Ultrasound Med. Biol. 2005, 31, 391-399. [CrossRef]

256. Wu, J.; Nyborg, W.L. Ultrasound, Cavitation Bubbles and Their Interaction with Cells. Adv. Drug Deliv. Rev. 2008, 60, 1103-1116. [CrossRef]

257. Helfield, B.; Chen, X.; Watkins, S.C.; Villanueva, F.S. Biophysical Insight into Mechanisms of Sonoporation. Proc. Natl. Acad. Sci. USA 2016, 113, 9983-9988. [CrossRef] [PubMed]

258. Mukherjee, D.; Wong, J.; Griffin, B.; Ellis, S.G.; Porter, T.; Sen, S.; Thomas, J.D. Ten-Fold Augmentation of Endothelial Uptake of Vascular Endothelial Growth Factor with Ultrasound after Systemic Administration. J. Am. Coll. Cardiol. 2000, 35, 1678-1686. [CrossRef] 
259. Zderic, V.; Clark, J.I.; Martin, R.W.; Vaezy, S. Ultrasound-Enhanced Transcorneal Drug Delivery. Cornea $2004,23,804-811$. [CrossRef] [PubMed]

260. Huber, P.E.; Pfisterer, P. In Vitro and in Vivo Transfection of Plasmid DNA in the Dunning Prostate Tumor R3327-AT1 Is Enhanced by Focused Ultrasound. Gene Ther. 2000, 17, 1516-1525. [CrossRef] [PubMed]

261. Hill, C.R. Ultrasonic Exposure Thresholds for Changes in Cells and Tissues. J. Acoust. Soc. Am. 1971, 90, 1971. [CrossRef]

262. Mitome, $\mathrm{H}$. The Mechanism of Generation of Acoustic Streaming. Electron. Commun. Jpn. 1998, 81, 1-8. [CrossRef]

263. Zhang, C.B.; Liu, Z.; Guo, X.S.; Zhang, D. Correlation between Microbubble-Induced Acoustic Cavitation and Hemolysis in Vitro. Chin. Phys. B 2011, 20, 024301. [CrossRef]

264. Tran, B.C.; Seo, J.; Hall, T.L.; Fowlkes, J.B.; Cain, C.A. Microbubble-Enhanced Cavitation for Noninvasive Ultrasound Surgery. IEEE Trans. Ultrason. Ferroelectr. Freq. Control. 2003, 50, 1296-1304. [CrossRef]

265. Kimmel, E. Cavitation Bioeffects. Crit. Rev. Biomed. Eng. 2006, 34, 105-161. [CrossRef] [PubMed]

266. Udroiu, I. Ultrasonic Drug Delivery in Oncology. J. BUON 2015, 20, 381-390.

267. Jelenc, J.; Jelenc, J.; Miklavčič, D.; Lebar, A.M. Low-Frequency Sonoporation in Vitro: Experimental System Evaluation. J. Mech. Eng. 2012, 58, 319-326. [CrossRef]

268. Liu, Z.; You, H.; Zhang, P.; Lin, R.; Chang, Y. Thermal Simulation and Sonoporation Experiment Based on a Focused Ultrasonic System. In Proceedings of the IOP Conference Series: Materials Science and Engineering, Cairo, Egypt, 7-9 April 2020; Volume 739 , p. 012037.

269. Jiang, X.; Savchenko, O.; Li, Y.; Qi, S.; Yang, T.; Zhang, W.; Chen, J. A Review of Low-Intensity Pulsed Ultrasound for Therapeutic Applications. IEEE Trans. Biomed. Eng. 2019, 66, 2704-2718. [CrossRef]

270. Burgess, M.T.; Porter, T.M. Control of Acoustic Cavitation for Efficient Sonoporation with Phase-Shift Nanoemulsions. Ultrasound Med. Biol. 2019, 45, 846-858. [CrossRef]

271. Sundaram, J.; Mellein, B.R.; Mitragotri, S. An Experimental and Theoretical Analysis of Ultrasound-Induced Permeabilization of Cell Membranes. Biophys. J. 2003, 84, 3087-3101. [CrossRef]

272. Wang, M.; Zhang, Y.; Cai, C.; Tu, J.; Guo, X.; Zhang, D. Sonoporation-Induced Cell Membrane Permeabilization and Cytoskeleton Disassembly at Varied Acoustic and Microbubble-Cell Parameters. Sci. Rep. 2018, 8, 3885. [CrossRef] [PubMed]

273. Wang, Y.; Bai, W.K.; Shen, E.; Hu, B. Sonoporation by Low-Frequency and Low-Power Ultrasound Enhances Chemotherapeutic Efficacy in Prostate Cancer Cells in Vitro. Oncol. Lett. 2013, 6, 495-498. [CrossRef] [PubMed]

274. Miller, D.L.; Pislaru, S.V.; Greenleaf, J.F. Sonoporation: Mechanical DNA Delivery by Ultrasonic Cavitation. Somat. Cell Mol. Genet. 2002, 27, 115-134. [CrossRef] [PubMed]

275. Liang, H.D.; Tang, J.; Halliwell, M. Sonoporation, Drug Delivery, and Gene Therapy. Proc. Inst. Mech. Eng. Part H 2010, 224, 343-361. [CrossRef]

276. Belling, J.N.; Heidenreich, L.K.; Tian, Z.; Mendoza, A.M.; Chiou, T.T.; Gong, Y.; Chen, N.Y.; Young, T.D.; Wattanatorn, N.; Park, J.H. Acoustofluidic Sonoporation for Gene Delivery to Human Hematopoietic Stem and Progenitor Cells. Proc. Natl. Acad. Sci. USA 2020, 117, 10976-10982. [CrossRef]

277. Dimcevski, G.; Kotopoulis, S.; Bjånes, T.; Hoem, D.; Schjøt, J.; Gjertsen, B.T.; Biermann, M.; Molven, A.; Sorbye, H.; McCormack, E.; et al. Human Clinical Trial Using Ultrasound and Microbubbles to Enhance Gemcitabine Treatment of Inoperable Pancreatic Cancer. J. Control. Release 2016, 243, 172-181. [CrossRef]

278. Lee, N.G.; Berry, J.L.; Lee, T.C.; Wang, A.T.; Honowitz, S.; Linn Murphree, A.; Varshney, N.; Hinton, D.R.; Fawzi, A.A. Sonoporation Enhances Chemotherapeutic Efficacy in Retinoblastoma Cells in Vitro. Investig. Ophthalmol. Vis. Sci. 2011, 52, 3868-3873. [CrossRef]

279. Hirabayashi, F.; Iwanaga, K.; Okinaga, T.; Takahashi, O.; Ariyoshi, W.; Suzuki, R.; Sugii, M.; Maruyama, K.; Tominaga, K.; Nishihara, T. Epidermal Growth Factor Receptor-Targeted Sonoporation with Microbubbles Enhances Therapeutic Efficacy in a Squamous Cell Carcinoma Model. PLoS ONE 2017, 12, e0185293. [CrossRef]

280. Qu, N.; Shi, D.; Shang, M.; Duan, S.; Guo, L.; Ning, S.; Li, J. Breast Cancer Cell Line Phenotype Affects Sonoporation Efficiency under Optimal Ultrasound Microbubble Conditions. Med. Sci. Monit. 2018, 24, 9054-9062. [CrossRef]

281. Shi, D.; Guo, L.; Duan, S.; Shang, M.; Meng, D.; Cheng, L.; Li, J. Influence of Tumor Cell Lines Derived from Different Tissue on Sonoporation Efficiency under Ultrasound Microbubble Treatment. Ultrason. Sonochem. 2017, 38, 598-603. [CrossRef]

282. Theek, B.; Baues, M.; Ojha, T.; Möckel, D.; Veettil, S.K.; Steitz, J.; Van Bloois, L.; Storm, G.; Kiessling, F.; Lammers, T. Sonoporation Enhances Liposome Accumulation and Penetration in Tumors with Low EPR. J. Control. Release 2016, 231, 77-85. [CrossRef] [PubMed]

283. Kotopoulis, S.; Delalande, A.; Popa, M.; Mamaeva, V.; Dimcevski, G.; Gilja, O.H.; Postema, M.; Gjertsen, B.T.; McCormack, E. Sonoporation-Enhanced Chemotherapy Significantly Reduces Primary Tumour Burden in an Orthotopic Pancreatic Cancer Xenograft. Mol. Imaging Biol. 2014, 16, 53-62. [CrossRef]

284. Zolochevska, O.; Xia, X.; Williams, B.J.; Ramsay, A.; Li, S.; Figueiredo, M.L. Sonoporation Delivery of Interleukin-27 Gene Therapy Efficiently Reduces Prostate Tumor Cell Growth in Vivo. Hum. Gene Ther. 2011, 22, 1537-1550. [CrossRef]

285. Kim, D.; Han, J.; Park, S.Y.; Kim, H.; Park, J.H.; Lee, H.J. Antitumor Efficacy of Focused Ultrasound-MFL Nanoparticles Combination Therapy in Mouse Breast Cancer Xenografts. Materials 2020, 13, 1099. [CrossRef]

286. Elhelf, I.A.S.; Albahar, H.; Shah, U.; Oto, A.; Cressman, E.; Almekkawy, M. High Intensity Focused Ultrasound: The Fundamentals, Clinical Applications and Research Trends. Diagn. Interv. Imaging 2018, 99, 349-359. [CrossRef] 
287. Dubinsky, T.J.; Cuevas, C.; Dighe, M.K.; Kolokythas, O.; Joo, H.H. High-Intensity Focused Ultrasound: Current Potential and Oncologic Applications. Am. J. Roentgenol. 2008, 190, 191-199. [CrossRef]

288. Wu, F.; Wang, Z.B.; Chen, W.Z.; Wang, W.; Gui, Y.; Zhang, M.; Zheng, G.; Zhou, Y.; Xu, G.; Li, M.; et al. Extracorporeal High Intensity Focused Ultrasound Ablation in the Treatment of 1038 Patients with Solid Carcinomas in China: An Overview. Ultrason. Sonochem. 2004, 11, 149-154. [CrossRef]

289. Kennedy, J.E.; Wu, F.; Ter Haar, G.R.; Gleeson, F.V.; Phillips, R.R.; Middleton, M.R.; Cranston, D. High-Intensity Focused Ultrasound for the Treatment of Liver Tumours. Ultrasonics 2004, 42, 931-935. [CrossRef] [PubMed]

290. Zhou, Y.-F. High Intensity Focused Ultrasound in Clinical Tumor Ablation. World J. Clin. Oncol. 2011, 2, 8-27. [CrossRef] [PubMed]

291. Wu, F.; Wang, Z.B.; Chen, W.Z.; Bai, J.; Zhu, H.; Qiao, T.Y. Preliminary Experience Using High Intensity Focused Ultrasound for the Treatment of Patients with Advanced Stage Renal Malignancy. J. Urol. 2003, 170, 2237-2240. [CrossRef]

292. Berge, V.; Dickinson, L.; McCartan, N.; Hindley, R.G.; Diep, L.M.; Emberton, M.; Ahmed, H.U. Morbidity Associated with Primary High Intensity Focused Ultrasound and Redo High Intensity Focused Ultrasound for Localized Prostate Cancer. J. Urol. 2014, 191, 1764-1769. [CrossRef]

293. Miller, D.L.; Smith, N.B.; Bailey, M.R.; Czarnota, G.J.; Hynynen, K.; Makin, I.R.S. Overview of Therapeutic Ultrasound Applications and Safety Considerations. J. Ultras Med. 2012, 31, 623-634. [CrossRef]

294. Tavakolinejad, A.; Rabbani, M.; Janmaleki, M. Effects of Hypergravity on Adipose-Derived Stem Cell Morphology, Mechanical Property and Proliferation. Biochem. Biophys. Res. Commun. 2015, 464, 473-479. [CrossRef] [PubMed]

295. Takemura, M.; Yoshida, S. Stimulation of DNA Polymerase $\alpha$ by Hypergravity Generated by Centrifugal Acceleration. Biochem. Biophys. Res. Commun. 2001, 289, 345-349. [CrossRef]

296. Thiel, C.S.; Tauber, S.; Christoffel, S.; Huge, A.; Lauber, B.A.; Polzer, J.; Paulsen, K.; Lier, H.; Engelmann, F.; Schmitz, B.; et al Rapid Coupling between Gravitational Forces and the Transcriptome in Human Myelomonocytic U937 Cells. Sci. Rep. 2018, 8, $1-24$.

297. Thiel, C.S.; Hauschild, S.; Tauber, S.; Paulsen, K.; Raig, C.; Raem, A.; Biskup, J.; Gutewort, A.; Hürlimann, E.; Unverdorben, F.; et al. Identification of Reference Genes in Human Myelomonocytic Cells for Gene Expression Studies in Altered Gravity. BioMed Res. Int. 2015, 2015, 363575. [CrossRef]

298. Costa-Almeida, R.; Carvalho, D.T.O.; Ferreira, M.J.S.; Pesqueira, T.; Monici, M.; van Loon, J.J.W.A.; Granja, P.L.; Gomes, M.E. Continuous Exposure to Simulated Hypergravity-Induced Changes in Proliferation, Morphology, and Gene Expression of Human Tendon Cells. Stem Cells Dev. 2018, 27, 858-869. [CrossRef] [PubMed]

299. Hemmersbach, R.; von der Wiesche, M.; Seibt, D. Ground-Based Experimental Platforms in Gravitational Biology and Human Physiology. Signal Transduct. 2006, 6, 381-387. [CrossRef]

300. Chen, Z.-Y.; Guo, S.; Li, B.-B.; Jiang, N.; Li, A.; Yan, H.-F.; Yang, H.-M.; Zhou, J.-L.; Li, C.-L.; Cui, Y. Effect of Weightlessness on the 3D Structure Formation and Physiologic Function of Human Cancer Cells. BioMed Res. Int. 2019, 2019, 4894083. [CrossRef]

301. Frett, T.; Petrat, G.; van Loon, J.J.; Hemmersbach, R.; Anken, R. Hypergravity Facilities in the ESA Ground-Based Facility Program-Current Research Activities and Future Tasks. Microgravity Sci. Technol. 2016, 28, 205-214. [CrossRef]

302. van Loon, J.J.W.A. The Human Centrifuge. Microgravity Sci. Technol. 2009, 21, 203-207. [CrossRef]

303. Kopp, S.; Krüger, M.; Feldmann, S.; Oltmann, H.; Schütte, A.; Schmitz, B.; Bauer, J.; Schulz, H.; Saar, K.; Huebner, N.; et al. Thyroid Cancer Cells in Space during the TEXUS-53 Sounding Rocket Mission-The THYROID Project OPEN. Sci. Rep. 2018, 8, 10355. [CrossRef] [PubMed]

304. Wehland, M.; Aleshcheva, G.; Schulz, H.; Saar, K.; Hübner, N.; Hemmersbach, R.; Braun, M.; Ma, X.; Frett, T.; Warnke, E.; et al. Differential Gene Expression of Human Chondrocytes Cultured under Short-Term Altered Gravity Conditions during Parabolic Flight Maneuvers. Cell Commun. Signal. 2015, 13, 1-13. [CrossRef]

305. Xu, D.; Guo, Y.B.; Zhang, M.; Sun, Y.Q. The Subsequent Biological Effects of Simulated Microgravity on Endothelial Cell Growth in HUVECs. Chin. J. Traumatol. 2018, 21, 229-237. [CrossRef] [PubMed]

306. Tschopp, A.; Cogoli, A. Hypergravity Promotes Cell Proliferation. Experientia 1983, 39, 1323-1329. [CrossRef] [PubMed]

307. Lei, X.; Cao, Y.; Zhang, Y.; Qian, J.; Zhao, Q.; Liu, F.; Zhang, T.; Zhou, J.; Gu, Y.; Xia, G.; et al. Effect of Microgravity on Proliferation and Differentiation of Embryonic Stem Cells in an Automated Culturing System during the TZ-1 Space Mission. Cell Prolif. 2018, 51, e12466. [CrossRef]

308. Kim, Y.J.; Jeong, A.J.; Kim, M.; Lee, C.; Ye, S.K.; Kim, S. Time-Averaged Simulated Microgravity (TaSMG) Inhibits Proliferation of Lymphoma Cells, L-540 and HDLM-2, Using a 3D Clinostat. Biomed. Eng. Online 2017, 16, 1-12. [CrossRef]

309. Sokolovskaya, A.A.; Ignashkova, T.I.; Bochenkova, A.V.; Moskovtsev, A.A.; Baranov, V.M.; Kubatiev, A.A. Effects of Simulated Microgravity on Cell Cycle in Human Endothelial Cells. Acta Astronaut. 2014, 99, 16-23. [CrossRef]

310. Arun, R.P.; Sivanesan, D.; Vidyasekar, P.; Verma, R.S. PTEN/FOXO3/AKT Pathway Regulates Cell Death and Mediates Morphogenetic Differentiation of Colorectal Cancer Cells under Simulated Microgravity. Sci. Rep. 2017, 7, 1-15. [CrossRef] [PubMed]

311. Rocca, A.; Marino, A.; Rocca, V.; Moscato, S.; de Vito, G.; Piazza, V.; Mazzolai, B.; Mattoli, V.; Ngo-Anh, T.J.; Ciofani, G. Barium Titanate Nanoparticles and Hypergravity Stimulation Improve Differentiation of Mesenchymal Stem Cells into Osteoblasts. Int. J. Nanomed. 2015, 10, 433-445. 
312. Montufar-Solis, D.; Duke, P.; D'Aunno, D. In Vivo and in Vitro Studies of Cartilage Differentiation in Altered Gravities. Adv. Sp. Res. 1996, 17, 193-199. [CrossRef]

313. Li, C.F.; Sun, J.X.; Gao, Y.; Shi, F.; Pan, Y.K.; Wang, Y.C.; Sun, X.Q. Clinorotation-Induced Autophagy via HDM2-P53-MTOR Pathway Enhances Cell Migration in Vascular Endothelial Cells. Cell Death Dis. 2018, 9, 147. [CrossRef]

314. Wang, Y.-C.; Lu, D.-Y.; Shi, F.; Zhang, S.; Yang, C.-B.; Wang, B.; Cao, X.-S.; Du, T.-Y.; Gao, Y.; Zhao, J.-D.; et al. Clinorotation Enhances Autophagy in Vascular Endothelial Cells. Biochem. Cell. Biol. Biol. Cell. 2013, 91, 309-314. [CrossRef] [PubMed]

315. Kang, C.Y.; Zou, L.; Yuan, M.; Wang, Y.; Li, T.Z.; Zhang, Y.; Wang, J.F.; Li, Y.; Deng, X.W.; Liu, C.T. Impact of Simulated Microgravity on Microvascular Endothelial Cell Apoptosis. Eur. J. Appl. Physiol. 2011, 111, 2131-2138. [CrossRef]

316. Sundaresan, A.; Risin, D.; Pellis, N.R. Cell growth in microgravity. In Encyclopedia of Molecular Cell Biology and Molecular Medicine; Meyers, R.A., Sendtko, A., Henheik, P., Eds.; Wiley-VCH: Weinheim, Germany, 2004; Volume 2, pp. 303-321.

317. Lambert, C.A.; Lapière, C.M.; Nusgens, B.V. Biology of adherent cells in microgravity. In Biology in Space and Life on Earth; Brinckmann, E., Ed.; Wiley-VCH: New York, NY, USA, 2007; pp. 123-155.

318. Rudimov, E.G.; Buravkova, L.B. Gravisensitivity of Endothelial Cells: The Role of Cytoskeleton and Adhesion Molecules. Hum. Physiol. 2016, 42, 687-693. [CrossRef]

319. Croute, F.; Gaubin, Y.; Pianezzi, B.; Soleilhavoup, J.P. Effects of Hypergravity on the Cell Shape and on the Organization of Cytoskeleton and Extracelluar Matrix Molecules of in Vitro Human Dermal Fibroblasts. Microgravity Sci. Technol. 1995, 8, 118-124. [PubMed]

320. Kelly, D.J.; Jacobs, C.R. The Role of Mechanical Signals in Regulating Chondrogenesis and Osteogenesis of Mesenchymal Stem Cells. Birth Defects Res. Part C 2010, 90, 75-85. [CrossRef]

321. Bacso, Z.; Nagy, H.; Goda, K.; Bene, L.; Fenyvesi, F.; Matkó, J.; Szabó, G. Raft and Cytoskeleton Associations of an ABC Transporter: P-Glycoprotein. Cytom. Part A 2004, 61, 105-116. [CrossRef]

322. Albi, E.; Curcio, F.; Lazzarini, A.; Floridi, A.; Cataldi, S.; Lazzarini, R.; Loreti, E.; Ferri, I.; Ambesi-Impiombato, F.S. A Firmer Understanding of the Effect of Hypergravity on Thyroid Tissue: Cholesterol and Thyrotropin Receptor. PLoS ONE 2014, 9, 5-11. [CrossRef]

323. Zhou, S.; Zu, Y.; Zhuang, F.; Yang, C. Hypergravity-Induced Enrichment of B1 Integrin on the Cell Membranes of Osteoblast-like Cells via Caveolae-Dependent Endocytosis. Biochem. Biophys. Res. Commun. 2015, 463, 928-933. [CrossRef]

324. Seguin, L.; Desgrosellier, J.S.; Weis, S.M.; Cheresh, D.A. Integrins and Cancer: Regulators of Cancer Stemness, Metastasis, and Drug Resistance. Trends Cell Biol. 2015, 25, 234-240. [CrossRef]

325. Janmaleki, M.; Pachenari, M.; Seyedpour, S.M.; Shahghadami, R.; Sanati-Nezhad, A. Impact of Simulated Microgravity on Cytoskeleton and Viscoelastic Properties of Endothelial Cell. Sci. Rep. 2016, 6, 1-11. [CrossRef] [PubMed]

326. Kuimova, M.K.; Yahioglu, G.; Ogilby, P.R. Singlet Oxygen in a Cell: Spatially Dependent Lifetimes and Quenching Rate Constants. J. Am. Chem. Soc. 2009, 131, 332-340. [CrossRef]

327. Renner, M.; Choquet, D.; Triller, A. Control of the Postsynaptic Membrane Viscosity. J. Neurosci. 2009, 29, 2926-2937. [CrossRef] [PubMed]

328. Kalwarczyk, T.; Ziębacz, N.; Bielejewska, A.; Zaboklicka, E.; Koynov, K.; Szymański, J.; Wilk, A.; Patkowski, A.; Gapiński, J.; Butt, H.-J.; et al. Comparative Analysis of Viscosity of Complex Liquids and Cytoplasm of Mammalian Cells at the Nanoscale. Nano Lett. 2011, 11, 2157-2163. [CrossRef]

329. Woodcock, E.M.; Girvan, P.; Eckert, J.; Lopez-Duarte, I.; Kubánková, M.; van Loon, J.J.W.A.; Brooks, N.J.; Kuimova, M.K. Measuring Intracellular Viscosity in Conditions of Hypergravity. Biophys. J. 2019, 116, 1984-1993. [CrossRef] [PubMed]

330. Kohn, F.P.M.; Hauslage, J. The Gravity Dependence of Pharmacodynamics: The Integration of Lidocaine into Membranes in Microgravity. Npj Microgravity 2019, 5, 5. [CrossRef]

331. Sieber, M.; Hanke, W.; Kohn, F.P.M. Modification of Membrane Fluidity by Gravity. Open J. Biophys. 2014, 4, 105-111. [CrossRef] 